\title{
The influence of bedrock orientation on the landscape evolution, surface morphology and denudation $\left({ }^{10} \mathrm{Be}\right)$ at the Niesen, Switzerland
}

Hannah Chittenden ${ }^{a}$, , Romain Delunela, Fritz Schlunegger ${ }^{a^{*}}$, Naki Akçara , Peter Kubik ${ }^{b}$

a Institute of Geological Sciences, University of Bern, 3012 Bern, Switzerland

b Institute of Particle Physics, ETH Hönggerberg, 8093 Zürich, Switzerland

* Corresponding author
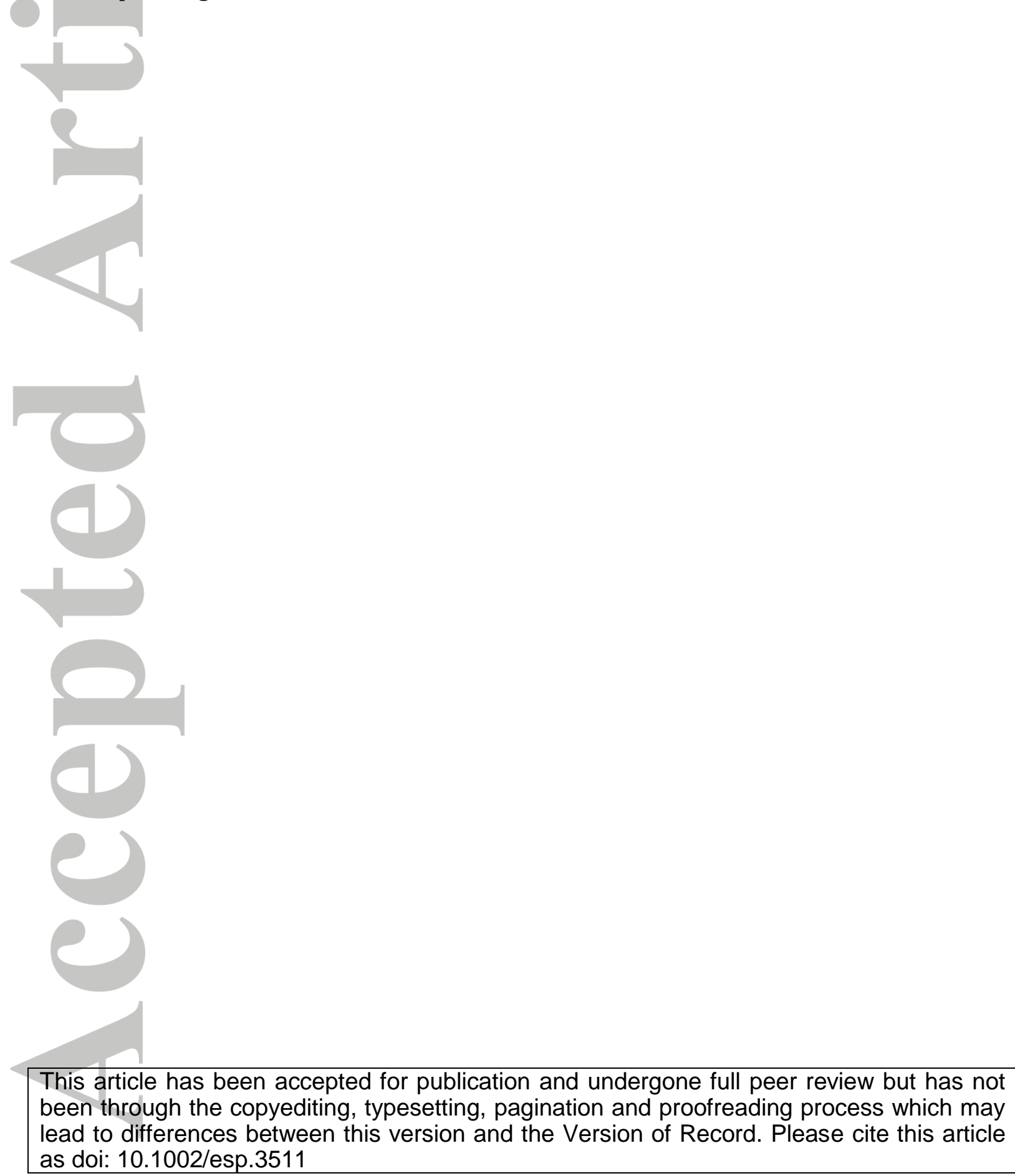

This article is protected by copyright. All rights reserved. 


\section{ABSTRACT}

Landscape evolution and surface morphology in mountainous settings are a function of the relative importance between sediment transport processes acting on hillslopes and in channels, modulated by climate variables. The Niesen nappe in the Swiss Penninic Prealps presents a unique setting in which opposite facing flanks host basins underlain by identical lithologies, but contrasting litho-tectonic architectures where lithologies either dip parallel to the topographic slope or in the opposite direction (i.e. dip slope and non-dip slope). The northwestern facing Diemtigen flank represents such a dip slope situation and is characterized by a gentle topography, low hillslope gradients, poorly dissected channels, and it hosts large landslides. In contrast, the southeastern facing Frutigen side can be described as non-dip slope flank with deeply incised bedrock channels, high mean hillslope gradients and high relief topography. Results from morphometric analysis reveal that noticeable differences in morphometric parameters can be related to the contrasts in the relative importance of the internal hillslopechannel system between both valley flanks. While the contrasting dip-orientations of the underlying flysch bedrock has promoted hillslope and channelized processes to contrasting extents and particularly the occurrence of large landslides on the dip slope flank, the flank averaged ${ }^{10} \mathrm{Be}$-derived denudation rates are very similar and range between 0.20 and $0.26 \mathrm{~mm} \mathrm{yr}^{-1}$. In addition, our denudation rates offer no direct relationship to basin's slope, area, steepness or concavity index, but reveal a positive correlation to mean basin elevation that we interpret as having been controlled by climatically driven factors such as frost-induced processes and orographic precipitation. Our findings illustrate that while the landscape properties in this part of the northern Alpine border can mainly be related to the tectonic architecture of the underlying bedrock, the denudation rates have a strong orographic control through elevation dependent mean annual temperature and precipitation.

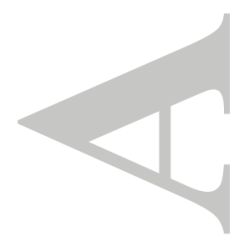

This article is protected by copyright. All rights reserved. 


\section{Introduction}

The morphology of the Swiss Alps largely records the imprints of the past glaciations, but has been modified during the Holocene by erosion and sediment transport in channels and on hillslopes (Schlunegger and Norton, 2013), which likewise also set the pace at which denudation has proceeded during the Holocene. While several studies have focused on interpreting either a tectonic (e.g., Safran et al., 2005; Binnie et al., 2007) or climate control (e.g., Bookhagen and Strecker, 2008; Schlunegger et al., 2011) on hillslope and channel form, and on erosion rate patterns (e.g., Barnes et al., 2012), less effort has been made on analyzing how the tectonic architecture influences the hillslope-channel ensemble. However, tectonic structures such as fractures and faults, and the nature of the bedrock lithology, do control the course of channels at the hillslope scale (Pazzaglia et al., 2007) and at that of an entire orogen (Kühni and Pfiffner, 2001) and likewise influence the production of sediment via channelized and hillslope erosion (Norton et al., 2011). An additional, yet poorly elaborated topic concerns the question of how orographic effects, either through temperature and/or precipitation gradients, might influence the pattern of surface erosion rates. Previous studies have emphasized orographic controls on precipitation (Frei and Schär, 1998), channel form (Schlunegger et al., 2011) weathering rates (Kober et al., 2007) and frost cracking processes (Delunel et al., 2010), but related consequences on erosion rates have not been explored for small catchments. This paper is designed to explore how orographic effects including precipitation and temperature gradients influence the denudation rate pattern at the scale of a mountain massif, and how erosional mechanisms are modulated by the isoclinal tilt of an entire flysch sequence.

The occurrence of hillslope and channelized processes is often coupled (Harvey, 2001; $2002 ; 2012$ ), however both deliver contrasting implications on topographic morphology and landscape development. While channelized erosion generally roughens topography and increases relief through stream incision into bedrock (positive feedback), hillslope processes have been found to reduce relief and smooth topography by filling depressions (negative feedback; e.g., Tucker and Slingerland, 1997; Schlunegger, 2002; Perron et al., 2009). Channelized erosional processes are activated when critical flow strength thresholds are exceeded, and processes rates are largely dependent on variations or fluctuations in runoff (Montgomery and Dietrich, 1992; Tucker and 
Slingerland, 1997). Erosion and sediment transport on hillslopes is primarily achieved through hillslope diffusion (soil creep), landsliding, rockfall and unchannelized overland flow (Anderson, 1994; Tucker and Slingerland 1996). Theoretical and numerical landscape evolution models point to the relative importance of sediment transport on hillslopes and in channels for explaining first order landscape properties, e.g., the branching of channels, their spacing, landscape relief and other metrics (Tucker and Slingerland, 1997; Simpson and Schlunegger, 2003; Perron et al., 2009).

Our study focuses on a particular situation offered by the Niesen nappe in the Swiss Penninic Prealps (Fig. 1), in which basins are underlain by identical rock types, however dip in opposite directions. In particular, the most distinguishable difference between the NW (Diemtigen) and SE (Frutigen) flanks is the tilt direction/orientation of the underlying bedrock relative to the topographic slope (i.e. dip slope vs. non-dip slope). The morphology of the northwestern side is defined by hillslopes with a gentle topography and shallow channels that run parallel to the dip direction of the underlying flysch bedrock. Contrastingly, the southeastern flank hosts several deeply incised bedrock channels that are bordered by high relief hillslopes where flysch dips perpendicular to the topographic slope.

Herein, we explore how erosional mechanisms at Niesen are modulated by the isoclinal tilt of an entire flysch sequence, and how this explains the distinct differences in the internal framework of the hillslope-channel system. In a second effort, we use in-situ produced cosmogenic ${ }^{10} \mathrm{Be}$ to investigate how the contrasts in the hillslope-channel ensemble influence the pattern of erosion rate pattern where climate variables reveal strong orographic trends.

\section{Setting}

The study site is located in the Alpine front ranges of the Bernese Oberland and is situated between the Frutigen and Diemtigen Valleys, ca. $60 \mathrm{~km}$ south of Bern, Switzerland. Our study region covers the northeast portion of the Niesen massif and the eastern most extent of the Niesen nappe (Figure 1), which extends from the Rhône Valley to Lake Thun (Caron et al., 1989). 


\subsection{Geology}

The Niesen nappe (Figure 1) is one of several allochthonous structural units that make up the Penninic Alpine front ranges (or Swiss Prealps/Penninic Klippen). Together, these SW-NE oriented units form the footwall of the frontal Penninic thrust (Caron et al., 1989). A Cenozoic flysch sequence and the Ultrahevetic and Helvetic realms define the southern Prealpine boundary. The Niesen nappe is made up of many large- and smallscale folds and is thrust directly overtop the Ultrahelvetics (Weidmann et al., 1976). It is tectonically constrained by the Ultrahelvetics and Helvetics in the Southeast and the overlying Zone Submédian and Penninc Klippen in the Northwest (Figure 2). The nappe itself is composed almost entirely of flysch-type sediments (Maastrichtian to Eocene) and crystalline basement slivers that were either displaced from their substratum during thrusting and nappe formation, or that were embedded into the flysch basin as exotic olistolites. The Niesen flysch is situated on top of an angular unconformity of Mesozoic meta-sediments and is characterized by a thick (400-1300m) series of clastic sediments such as sandstones, conglomerates, basement clasts and shales. Overall, the flysch deposits are very coarse-grained and packages illustrate a fining upward sequence, typical of deep-sea fan environments. Depositional units within the study region include (from oldest to youngest, Figure 2): Frutigen Flysch, Niesenkulm Flysch and Seron Flysch (Ackermann, 1986). The Frutigen Flysch is exclusive to the SE (Frutigen) flank of the Niesen. It is made up of clast-supported conglomerates, sandstones and turbiditic shales and has a maximum thickness of ca. $750 \mathrm{~m}$. The Niesenkulm Flysch is situated predominantly on the ridge dividing the NW Diemtigen and SW Frutigen Valleys. Sediments here can be described as coarse-grained sandstones overlain by medium- to fine-grained turbidites. Bedding thickness increases from $100 \mathrm{~m}$ in the west, to approximately $250 \mathrm{~m}$ in the east (Ackermann, 1986). The Seron Flysch is found almost exclusively on the NW (Diemtigen) flank of the Niesen nappe. The base of this unit is made up of massive-bedded conglomerates with sandstone alternations, while the top exhibits clast-supported conglomerate and mudstone alterations. A more exhaustive sedimentological interpretation can be found from the works of Ackermann (1986).

On the Frutigen side, bedding and foliations (schistosity) of the flysch sequences strike in the opposite direction to the topographic slope (non-dip slope). Dip angles of bedrock range from $25^{\circ}$ to $45^{\circ}$ and are oriented between $260-320^{\circ} \mathrm{NW}$. In contrast, on the 
Diemtigen side, the bedrock architecture represents a dip slope situation where the tiltazimuth of bedrock parallels the topographic slope. Dip angles of bedrock are between $25^{\circ}$ and $40^{\circ}$, while dip orientation ranges from $230^{\circ}$ to $312^{\circ}$, and the majority of bedrock orientations dip towards the NW. Despite noticeable physical differences on both sides, the erodibility is relatively identical, as illustrated by Kühni and Pfiffner (2001). Likewise, upon mapping lithological characteristics (e.g. grain/clast size, rock type and composition) are remarkably similar (Ackermann, 1986). This implies that the erosional resistance for rivers, hillslope processes, or glaciers should be nearly the same or potential differences are at least not measurable with current tools. Likewise, rock uplift rates are nearly indistinguishable in the entire study area (Schlatter et al., 2005).

\subsection{Geomorphology}

Preliminary field analyses of the NW and SE Niesen revealed distinct contrasts in characteristics such as drainage density, incision patterns, channel orders (Figure 3), lithological contacts and bedrock exposure (Figure 2). The SE non-dip slope flank of the Niesen (Figures 2, 3) hosts a high-relief landscape with a closely spaced network of deeply incised bedrock channels ( 100-200m) and significantly less regolith cover than the Diemtigen side (Figure 2A). In contrast, the dip slope Diemtigen flank of the Niesen nappe is characterized by a smooth, gentle and less dissected topography (100-120 m, Figure 3) and hosts several deep-seated landslides (Figure 2). Both sides of the Niesen nappe host erosional (imprints of glacial cirques) and depositional features (m's thick unconsolidated till) related to Quaternary glaciations, where ice thickness during the Last Glacial Maximum (LGM) exceeded 500 m (Kelly et al. 2004; Bini et al., 2009).

\section{Methods}

\subsection{Morphology and morphometry}

We complemented the results of preliminary investigations (Figures 2, 3) with an assessment of morphometric parameters for a total of nine catchments at the Niesen (N1-N9, Figure 2). Geomorphometric parameters were calculated using the Swisstopo Lidar DEM with a horizontal resolution of $2 \mathrm{~m}$ as a basis. All calculations were performed within a standard GIS environment, thereby including slope, steepness and concavities of channels, stream order and channel densities, following the methodology presented by Norton et al., (2011). The mean slope of each analyzed watershed is 
described here as the maximum rate of change between each cell and its neighbors. This variable was calculated using a 3 × 3 cells sliding window to gather a collective average of all slope angles (Figure 4) within our selected catchments (Norton et al., 2011). The relative uncertainties associated with mean elevation, slope and drainage areas are calculated as Standard Error of the Mean (SEM) according to Strahler (1954):

$$
S E M=\sigma / \sqrt{n}
$$

where $\sigma$ and $n$ are the standard deviation of the considered variable and the number of pixel represented by the catchment, respectively. Due to the size of the studied catchments and the resolution of the DEM $(2 \mathrm{~m})$, the relative SEMs are systematically smaller than $1 \%$.

Channel metrics, and particularly steepness and concavity values, have been shown to be positively correlated with the erosional efficiency of a channel (Safran et al., 2005; Ouimet et al., 2009; DiBiase et al., 2010). In particular, a deeply dissected stream with a high erosional efficiency will have higher steepness and concavity values than a stream where dissection has been less (Figure 5A). Accordingly, we extracted these variables based on empirical relationships between the upstream size of a basin $A$ and the channel gradient $S$ (Flint, 1974):

$$
S=k_{s} A^{-\theta}
$$

where $k_{s}$ and $\theta$ express the channel steepness and concavity index, respectively. Stream profiles were extracted from the DEM using a $250 \mathrm{~m}$ smoothing window (radius along stream length) and a $10 \mathrm{~m}$ sampling contour interval for each catchment. They were subsequently used to produce slope-area plots, from which steepness and concavity indices were calculated according to equation (2). We used the MATLAB® script developed by Wobus et al. (2006) for this task. Note that all upstream sections that have been deemed 'excusively alluvial', i.e. those where the contributing catchment size is less than 100'000-500'000 $\mathrm{m}^{2}$ (Norton et al., 2008), have been omitted from this analysis, mainly because channels in these catchments may predominantly have been shaped by debris flow processes (Lague and Davy, 2003), as illustrated by many examples in the Alps (e.g., Brardinoni et al., 2012). Likewise, we removed those channel segments that are situated in glacial cirques, because of the strong glacial controls on channel forms in these segments. From the remaining fluvial part of the channel profiles, steepness values were normalized to a reference concavity $\theta_{\text {ref }}$ of 0.45 (Wobus 
et al., 2006; Korup, 2006) in order to compare between opposite flanks and with related studies (Wobus et al., 2006, Ouimet et al., 2009). As already indicated above, streams with higher steepness (intercept with the y-axis) and concavity values (slope of regression line) are expected to be more erosive than those where concavity and steepness values are low (Figure 5A). Finally, geomorphologic maps have been established by Ackermann (1986), Caduff (2008) and Fischli (2010), whose results are presented here in Figure 2A and expanded by our own observations. These were used to identify the relative importance of hillslope processes such as landsliding versus dissection in channels, which will be considered as the basis for interpreting the patterns of mean slopes, channel density and erosion rates.

\subsection{Sampling strategy for ${ }^{10} \mathrm{Be}$ analyses}

Catchment-averaged denudation rates were measured using in-situ ${ }^{10} \mathrm{Be}$ (e.g., Matmon et al., 2003; von Blanckenburg, 2005; Wittmann et al., 2007). A total of $7 \mathrm{~kg}$ of riverborne sediments (sandstones, conglomerates, clays, 5-10\% quartz) were collected from 9 sites, representative of trunk and tributary channels (Figure 2). Special attention was paid to ensure that sediment had been supplied by fluvial processes and not by mass wasting from the surrounding hillslopes, because this might perturb the ${ }^{10} \mathrm{Be}$ signal by a local component (Niemi et al., 2005). Accordingly, 4 samples were taken from the Frutigen side slightly upstream from the tributary-trunk stream junction, while five samples were collected from the Diemtigen valley side; 3 of which were tributaries and 2 from upstream and downstream locations along the Chirel River, which is the trunk stream in this region (Figure 2). The rationale for sampling the trunk stream was to examine the influence of landsliding on the calculated basin-averaged denudation rate (the landslides transfer the material to the trunk channel, which might influence the denudation rate pattern, Figure 2), a process, which has been considered negligible on the SE Frutigen flank, as identified by mapping (Figure 2A). The samples were then dried and sieved to $0.25-0.5$ and $0.5-1 \mathrm{~mm}$-size fractions, where the later were subsequently crushed to $0.25-0.5 \mathrm{~mm}$. The non-magnetic fractions of each sample were separated using a Franz isodynamic magnetic separator and $\sim 500 \mathrm{~g}$ of each sample was prepared for sequential chemical dissolution. In the first phase of quartz purification, $5 \% \mathrm{HCl}$ was used to remove carbonate and organic components from the samples. Samples were then treated three times with 5\% HF and three additional times with 
2.5\% HF in order to eliminate mineral impurities (e.g. oxides, carbonates and feldspars), as well as to efficiently remove adsorbed meteoric components (Kohl and Nishiizumi, 1992; Akçar, 2006). In a final stage of mineral dissolution, a solution of $\mathrm{HCl}$ and $\mathrm{HNO}_{3}$ (Aqua Regia) was used to remove metallic components as well as any left over carbonates or organics. The following stages were completed following procedures outlined by Akçar et al. (2012). The remaining 'pure' quartz was dissolved in concentrated (48\%) HF once ca. $0.2 \mathrm{mg}$ of ${ }^{9} \mathrm{Be}$ carrier (spike) had been added to each sample. It was at this stage that we recognized that samples N6 and N7 contained insufficient amounts of quartz. These samples were therefore excluded from any further analysis. Following ion exchange column separation techniques and the oxidation of precipitated Beryllium hydroxide $\left[\mathrm{Be}(\mathrm{OH})_{2}\right]$, the final precipitate $(\mathrm{Be} / \mathrm{Fe})$ was mixed with $\mathrm{AgNO}_{3}$ and subsequently pressed into targets (Akçar et al., 2012). The ${ }^{10} \mathrm{Be} /{ }^{9} \mathrm{Be}$ ratios were normalized to ETH in-house standard S2007N (Kubik and Christl, 2010) based on the ${ }^{10} \mathrm{Be}$ half-life of $1.39 \pm 0.01$ Ma (Korschinek et al., 2010; Chmeleff et al., 2010). A full process blank ratio of (2.82 \pm 0.29$) \times 10^{-15}$ was subtracted from all ratios, and the error was then propagated into the concentration uncertainties.

\subsection{Calculations and scaling}

Using the measured ${ }^{10} \mathrm{Be} /{ }^{9} \mathrm{Be}$ ratios, all catchment-wide, basin-averaged erosion rates were calculated using the CRONUS-Earth calculator version 2.2 (Balco et al., 2008; http://hess.ess.washington.edu/) using the time-dependent spallogenic production scaling scheme of Lal (1991) and Stone (2000). This scaling scheme assumes a reference spallogenic ${ }^{10} \mathrm{Be}$ production rate of $4.49 \pm 0.39$ atoms $\mathrm{g}^{-1} \mathrm{yr}^{-1}$, and uncertainties are treated as functions of both internal and external errors (see Balco et al., 2008 for descriptions of uncertainties associated with various scaling schemes). Scaling factors are used to explain variations in nuclide production rates as a function of latitude, altitude and time. Although the CRONUS-Earth calculator does not employ an optimized attenuation depth function, our mean elevation and latitude measurements are sufficient since the sampled catchments do not cover a large range in elevation and calculated erosion rates are not exceptionally high and thus much lower than 1-2 mm $\mathrm{yr}^{-1}$ (Balco et al., 2008; Norton et al., 2008; Van den Berg et al., 2012). We assigned rock density values $(\rho)$ of 2.0 g. $\mathrm{cm}^{-3}$ and 2.55 g. $\mathrm{cm}^{-3}$ to unconsolidated quaternary deposits and bedrock in the upstream catchment, respectively. The relative proportion of these 
units has been taken from geomorphological maps (Figures 2, 3). Production rates were corrected for topographic shielding following the methodology of Norton and Vanacker (2009), and these factors were derived using basin elevation variances from our $2 \mathrm{~m}$ DEM. No algorithms were required to correct for scale dependence of shielding (Norton and Vanacker, 2009) due to our access to fine resolution digital elevation models. Snow cover shielding corrections were calculated using the snow cover function of Norton et al. (2010) and Swiss snow data from Auer (2003). Note that because snow thickness data for Niesen are not available, we had to use the more general dataset by Auer, which will add a bias in our denudation rates estimates because snow thicknesses have been calculated using the concept of regionalization. We also note that we are not able to quantify the potential bias due to a lack of constraints. Total uncertainties are reported as a combination of internal and external errors, and these have been propagated into all denudation rates. Erosional integration times (or minimum ${ }^{10} \mathrm{Be}$ erosional time scales, Table 3) are calculated as the amount of time required to remove approximately $60 \mathrm{~cm}$ of material (i.e. equivalent to the apparent attenuation length; see Dunai, 2010). No corrections were made for uplift or paleomagnetic and solar variations. All data representing morphometric and cosmogenic nuclide data together with ${ }^{10} \mathrm{Be}$-based denudation rates are presented in Tables 2, 3 and 4.

\subsection{Precipitation and temperature data}

Mean annual precipitation and air temperature in the vicinity of the Bernese Oberland were compiled from the MeteoSwiss database in order to estimate the potential control of climate on denudation rates in the Niesen area. Both precipitation and temperature data consist of 30-year climate norm values that are averaged over the period 19812010. The precipitation database has been compiled from 36 stations located in the western part of the Swiss plateau and of the northern slopes of the Swiss Alps (Figure 1 and Table 1). It mainly corresponds to the immediate vicinity of the Bernese Oberland and its foothills on the north. For simplicity, we will refer to the area as Bernese Oberland in the following sections. The climate in this area is spatially homogeneous (Baeriswyl and Rebetez, 1997), representing the wettest region in Switzerland and marked by abundant summer precipitation. The temperature parameters were only available for ten of these stations and correspond to the mean, maximum and minimum 
annual air temperature as well as the frost frequency (i.e. the number of days per year where the minimum air temperature is negative).

\section{Results}

\subsection{Morphology and morphometrics}

The analyzed basins from the Frutigen flank (N1-N4) reveal moderately high and uniform mean hillslope angles where gradients range from approximately $31^{\circ}$ to $36^{\circ}$. Measured hillslope angles on the Diemtigen (dip slope) side (N5-N9) are slightly lower and show less disparity in adjacent catchments, with mean values between $27^{\circ}$ and $29^{\circ}$ (Table 2). Likewise, the slope distributions show distinct differences (Figure 4). Slope values from the upper reaches of Diemtigen catchments (dip slope) are similar to those of the Frutigen (non-dip slope) (pointing to the presence of glacial cirques, Figure 2A), however on the Diemtigen side, hillslopes are steep in the uppermost segments of the basins and then flatten out downstream, illustrating the effects of landslides. This relationship is less clear on the Frutigen side where the basins show relatively steep gradients throughout the entire catchment. Also on the Frutigen side, steepest hillslope gradients $\left(<50^{\circ}\right)$ are measured along the lowest segments of the catchments (near sampling sites), thus pointing to the deep bedrock incision on this flank (Figure 2A). In contrast, the lowest third segments of the Diemtigen (dip slope) catchments have very low hillslope angles.

The consideration of maximum depths of incisions yields the same pattern, where catchments on the Frutigen flank are up to 100-200 m deeply incised, while maximum depths of catchments on the dip slope Diemtigen side range between 100-120 m (Figure 3). Likewise, the non-dip slope Frutigen side has been dissected by a relatively dense network ( $\left.>1.5 \mathrm{~km}^{-1}\right)$ of 2 to 3 order channels, while only first order channels have been mapped on the Frutigen side where the channel density is much less (ca. $0.5 \mathrm{~km}^{-1}$ ).

Slope-area plots and longitudinal stream profiles (Figure 5B) illustrate differences between the two flanks of the Niesen. Stream profiles on the non-dip slope Frutigen side all show smooth concave-up geometries and, with the exception of $\mathrm{N} 1$, we observe no visible knickzones (Figure 5B1). Concavity index $\theta$ values range from 0.38 to 2 . In contrast, channels on the NW Diemtigen (dip slope) have relatively straight to slightly convex profiles, with concavities between -0.09 to 0.12 (Figure 5B2). An exception here is the trunk channel that has a concavity of ca. 0.5 as is expected for non-perturbed 
normally graded streams (Korup, 2006). It should be noted that the slight 'bumps' in the Diemtigen profiles are due to irregularities in the landscape caused by Holocene glaciers and/or landslides (Caduff, 2008; Figure 2), and are not a result of disturbances by tectonic faults. Normalized channel steepness index $\left(K_{s n}\right)$ values for fluvial channels on the Frutigen and Diemtigen flanks range from from 180 to $241 \mathrm{~m}^{0.9}$ and 119 to $176 \mathrm{~m}^{0.9}$ respectively. Note that these units including the dimensions derive directly from solutions of equation (1). Concavity increases with mean basin slope, where angles above $32^{\circ}$ have likewise $\theta$ values higher than 0.38 (Figure 6). Again, since these parameters have been extracted from a 2 m lidar DEM that does not show any obvious offsets or artefacts, we considered these values to be robust.

\section{2 ${ }^{10}$ Be derived denudation rates}

Basin averaged denudation rates from the non-dip slope Frutigen and dip slope Diemtigen catchments are presented in Table 4 and summarized in Figures 4 and 7. The ${ }^{10} \mathrm{Be}$ derived denudation rates from all sampled catchments yield rates between $0.055 \pm$ $0.003 \mathrm{~mm} \mathrm{yr}^{-1}$ to $0.422 \pm 0.048 \mathrm{~mm} \mathrm{yr}^{-1}$. Interestingly, low $\left(0.055 \mathrm{~mm} \mathrm{yr}^{-1}\right)$ and high rates $\left(0.359 \mathrm{~mm} \mathrm{yr}^{-1}\right)$ are both derived from adjacent catchments on the Frutigen flank $(\mathrm{N} 2, \mathrm{~N} 3)$. Rates from both sides suggest minimum ${ }^{10} \mathrm{Be}$ integration timescales between 1900 and 11700 yrs (Table 4). The denudation rates on the Diemtigen side have also a large spread, where N5 and N8 differ by ca. $0.15 \pm 0.064 \mathrm{~mm} \mathrm{yr}^{-1}$. These two basins are eroding at least twice as quickly as the western upstream catchment (N9, trunk stream), where a rate of $0.102 \pm 0.009 \mathrm{~mm} \mathrm{yr}^{-1}$ is measured. Despite these contrasts, mean denudation rates for Diemtigen and Frutigen are essentially identical and range between $0.20 \pm 0.008$ and $0.26 \mathrm{~mm} \pm 0.023 \mathrm{yr}^{-1}$. Basin averaged denudation rates presented here have no correlation with mean slope (Figure $7 \mathrm{~b}$ ), mean basin area (Figure 8c) or channel steepness and concavity index (Figure 7d, 7e). A positive relationship does however exist between mean basin elevation and denudation rate with $\mathrm{r}^{2}=0.85$ (Figure $7 \mathrm{a}$ ), where denudation rates steadily increase with mean basin elevations.

\subsection{Precipitation and temperature data}

Annual precipitation and temperature parameters (i.e. mean, maximum and minimum air temperature and frost frequency) are presented in Table 1. Figure 8 represents the 
distribution of annual precipitation and temperature parameters as a function of elevation in the vicinity of the Bernese Oberland. It shows that the annual precipitations increase from ca. $1000 \mathrm{~mm}$ at low elevation (i.e. $<500 \mathrm{~m}$ ) to $>1500 \mathrm{~mm}$ at higher elevations and follow a general linear trend. The relationship between annual precipitation and elevation reveals the existence of an orographic gradient at the scale of the northern slopes of the western Swiss Alps. The scattering of the precipitation demonstrates however that slope and shielding effects are likely to control the distribution of precipitation in this area (Frei and Schaer, 1998). Assuming that the altitudinal gradient of precipitation in the region is significant and in agreement with values observed in the neighboring stations of Niesen (i.e. Wimmis, Frutigen, Zweisimmen and Erlenbach Im Simmental, Table 1), we infer that the annual precipitation in the Niesen massif vary from ca. $1200 \mathrm{~mm} \mathrm{yr}^{-1}$ at $700 \mathrm{~m}$ to $<2000 \mathrm{~mm} \mathrm{yr}^{-}$ 1 at $2400 \mathrm{~m}$.

The mean annual air temperatures varies from ca. $10^{\circ} \mathrm{C}$ at $<500 \mathrm{~m}$ to $-7.2^{\circ} \mathrm{C}$ at the Jungfraujoch (3580 m, Table 1) in the Bernese Oberland. Figures 7B and C reveal that all temperature parameters are perfectly correlated to the elevation in the Bernese Oberland (i.e. the temperature decreases as a function of elevation, leading the frostfrequency to increase). Based on the linear relationship between mean air temperature/sfrost-frequency and elevation, we estimate that the mean annual air temperature varies between ca. $8^{\circ} \mathrm{C}$ and $0^{\circ} \mathrm{C}$ while the frost-frequency likely doubles, i.e from c.a. 100 days $\mathrm{yr}^{-1}$ to $>200$ days $\mathrm{yr}^{-1}$, between the foot and top of the Niesen, respectively.

\section{Discussion}

\subsection{Potential biases in the erosion rate calculations}

Four potential biases could affect our interpretation of the erosion rate data. These are presented in the following paragraphs before discussion of the general picture of erosional mechanisms and rates. First, the denudation rates have been calculated under the assumption that the collected ${ }^{10} \mathrm{Be}$ samples are well mixed and representative of the entire upstream area where the distribution of quartz in bedrock is considered to be homogeneous. At this stage, we cannot rule out nor can we quantify possible uncertainties in the denudation rate estimates that might be attributed to stochastic sediment supply by landsliding and debris flows. Indeed, as has been discussed by 
Niemi et al. (2005), the effect of landsliding on CRN-derived erosion rates is very difficult, or almost impossible, to quantify. Second, current erosion rates and patterns, as well as a channels' efficiency in eroding landscapes, could strongly owe to the overprint created by past alpine glaciations (Norton et al., 2010a). In this regard, both sides have glacial cirques in the headwaters that are nearly identical in widths, depths and curvatures (Fischli, 2010; Figure 2A), and both flanks have experienced substantial and similar glacial sculpting/overprinting during LGM times (Bini et al., 2009). We can therefore not attribute contrasting landscape morphologies to differences in glacial conditioning between the Frutigen and Diemtigen sides, nor can we use this mechanism to interpret the spatial distribution of inferred denudation rates in the Niesen. Note also that because ${ }^{10} \mathrm{Be}$-based denudation rates integrate the erosional history of the past ca. 6000-2000 yr, we do not consider that differential glacial retreat might have controlled the observed pattern. An exception here is catchment N2 where erosion rates are very low. However, this basin lacks evidence of a strong glacial imprint (i.e. cirques and moraines, Figures 2, 3). Third, recycling of glaciogenic material that is characterized with non-predictable inherited ${ }^{10} \mathrm{Be}$ concentrations might further bias the inferred denudation rates (Wittmann et al., 2007; Delunel et al., 2013). However, acknowledging that we cannot quantify these potential biases at the Niesen, we anticipate that they cannot successfully explain the observed relationships between denudation rates and elevation due to the spatial distribution of glacial till (preferentially localized on the NW dip slope flank) and cirques (located on both side). Moreover, the potential incorporation of sediment eroded from surfaces that not have reached a steady-state equilibrium since the ice-retreat $15 \mathrm{kyr}$ ago would imply that the denudation rates inferred from ${ }^{10} \mathrm{Be}$ analyses are overestimated by up to $\sim 30 \%$ for the basins affected by the lowest denudation rates (Glotzbach et al., 2013). If proven, such an overestimation of the ${ }^{10} \mathrm{Be}$ inferred denudation rates would even make the relationships between denudation rates and mean basin elevation stronger at the Niesen (i.e. the altitudinal gradient of denudation rates would increase). Fourth, possible heterogeneities in quartz-bearing lithologies might bias our denudation rates as well. Further detailed studies (e.g., time series and mixing modeling of ${ }^{10} \mathrm{Be}$ concentrations or provenance tracing; Kober et al., 2012; Savi et al., 2013; Delunel et al., 2013) would be required to quantify possible uncertainties related to lithological effects and recycling of glaciogenic material. 
Despite these potential drawbacks, basin averaged denudation rates in our study area are in accordance with rates from basins with similar bedrock lithologies (Palumbo et al., 2009, Ouimet et al., 2009, Norton et al., 2011), yet rates appear to be more comparable to basins from the Alpine Foreland (Wittmann et al., 2007, Norton et al., 2011; Van den Berg et al., 2012). In contrast to these studies, however, we have identified no relationships between basin averaged denudation rates and hillslope metrics at the Niesen. Our results also reveal that geomorphological differences are less reflected in patterns of denudation rates and sediment discharge as previous studies (Schwab et al., 2009) have inferred for similar situations, probably because the ${ }^{10} \mathrm{Be}-$ based denudation rates integrate more time than photogrammetry-based detection of changes.

\subsection{Landscape morphology: Control of bedrock orientation}

According to numerical models (Tucker and Slingerland, 1997; van der Beek and Braun, 1998; Simpson and Schlunegger, 2003), differences in hillslope-channel arrangements in general, and channel spacing and depths of incision in particular (Figure 3), could either reflect variations in the states of the evolutionary development of landscapes or contrasts in the relative importance between sediment discharge on hillslopes and in channels, provided that all other parameters were constant. If the former case (i.e. contrasts in evolutionary states) applies to the landscape at Niesen, we would expect systematic relationships between the metric variables and denudation rates. This is illustrated here by the following example. Let us assume that an originally nondissected and inclined ramp starts to experience erosion. Numerical models have shown that in this case, channels start to form in the lower segments of this ramp, from where they will shift their heads (or point of initiation) towards higher elevations by headward retreat (e.g., Tucker and Slingerland, 1997). This process of headward erosion is likewise associated by an increase in the density and branching of channels, with the result that higher order trunk channels will form as time proceeds (van der Beek and Braun, 1998). Also, the depth of incision will increase as headward erosion continues.

Such a development towards a more dissected landscape will also be associated by an increase in erosion rates where an initially poorly dissected ramp experiences slow erosion, while a more dissected ramp with a higher channel density will be eroded faster (also according to numerical models by authors cited above). Accordingly, it is 
possible to interpret the poorly dissected ramp of the dip slope Diemtigen side to reflect an early immature state of landscape development where erosion operates slowly. In contrast, following the same concept, the deeply dissected non-dip slope Frutigen side could then be interpreted as a landscape where headward erosion has proceeded farther towards the headwaters, thereby forming deeply incised channels. In support of these hypotheses, the high concavity and steepness values of channels on the non-dip slope Frutigen side (Figure 5B2) would support the interpretation of fast erosion in the channel network. Similarly, high concavity values of channels and mean basin slopes, also measured for the non-dip slope Frutigen side (Figure 6), could additionally be used as evidence for fast erosion, as documented for instance in the Bolivian Andes (Safran et al., 2005). However, our data suggest that this is not the case here because basin averaged ${ }^{10} \mathrm{Be}$ denudation data show a large spread of rates which lack a distinct correlation to landscape metrics (except for elevation a.s.l.). In addition, the average denudation rates of the Diemtigen and Frutigen flanks differ by 0.05-0.06 mm yr-1, or by ca. $30 \%$. This is within the range of natural variability of denudation rates measured within individual catchments (e.g. Wittmann et al., 2007) and we therefore consider the erosion rates to be equal. In conclusion, differences in landscape properties between the Diemtigen and Frutigen sides (Figure 3) cannot be explained by contrasts in the evolutionary states between both sides.

Alternatively, also according to conceptual models of landscape evolution, landscape metrics including the spacing between channels and steepness/concavity patterns of channel longitudinal profiles can be considered as function of the relative importance of sediment discharge by hillslopes and channelized processes (van der Beek and Braun, 1998; Simpson and Schlunegger, 2003; Perron et al., 2009). In particular, these models suggest that landscapes where sediment discharge has mainly been accomplished through hillslope processes (e.g., landsliding, or alternatively also large rockfalls) will display a less stable network of poorly dissected channels, mainly because high slip rates of unconsolidated hillslope material tend to retard or inhibit the establishment of a stable channel network. Such a landscape will host low-order, poorly branched channels with a relatively large lateral spacing and limited depths of dissection (Figure 3C). This appears to be the case at the Niesen, where field observations and mapping have revealed (Figure 2) that deep-seated landslides are prominent features on the dip slope Diemtigen flank. The opposite has been inferred for the non-dip slope Frutigen 
side, also based on field observations and mapping (Figure 2), where evidence for deepseated landslides and evidence for large rockfalls and rock avalanches are missing. There, the channel density and the depth of dissection are high, channels are branched and of high order, have a high steepness and concavity index, and the lateral spacing between them is low. Conceptual models have shown that such a landscape is characterized by relatively stable hillslopes, thus allowing streams to establish a highlybranched network of deeply dissected channels (van der Beek and Braun, 1998; Simpson and Schunegger, 2003; Perron et al., 2006; Figure 3C). This is also reflected in the relatively high values for mean basin slope and channel concavity index on the nondip slope Frutigen side (Figure 6). In such a situation, threshold angles of hillslopes tend to be higher if the beds or foliations dip obliquely or opposite to the topographic slope (e.g., Roering et al., 2005), thereby allowing channels to deeply incise into bedrock and to form steep and highly concave profiles. We therefore interpret the present day morphology at the Niesen, and particularly the contrasts in channel density, hillslope steepness and channel metrics between the Frutigen and Diemtigen sides, as a direct consequence of the differences in the relative importance of sediment discharge on hillslopes and in channels. This highlights and confirms the dependence of rock type on landscape morphology in general and landsliding in particular (e.g., Brocard and van der Beek, 2006; Norton et al., 2011; Bishop and Goldrick, 2010).

\subsection{Orographic erosion}

While landscape form and erosional mechanisms have been related to the bedrock architecture in the previous sections, the rates at which erosion has occurred on both sides might be best related here to the local climate of the Niesen, as pointed out by the positive relationship between ${ }^{10} \mathrm{Be}$-based denudation rates and mean catchment altitudes (Figure 7a). The hypothesis of such a potential climate control on denudation rates in the Niesen is thus pinpointed by the existence of altitudinal gradients in the spatial distribution of both annual precipitation and temperature settings (Figure 8). First, we have shown that annual precipitation, mean monthly air temperature and frost-frequency are all scaling linearly with elevation in the Bernese Oberland. Moreover, the particular pyramidal architecture of the Niesen topography and its original situation localized between the foothills and the main divides of the Alps (i.e. Niesen is among the first elevated summit/barrier facing the air mass coming from the 
north) likely make this massif exposed to orographic precipitation. This situation implies that the highest area of the Niesen receives stronger annual precipitations in general. Second, the altitudinal gradients observed in the temperature parameters implies that the highest areas of the Niesen are likely more exposed to efficient frostcontrolled erosive processes such as frost cracking (Hales and Roering, 2007; Delunel et al., 2010). Indeed, with mean annual temperature of just above freezing along the highest summits and ridgelines of Niesen frost-cracking efficiency is at its maximum (Hales and Roering, 2007). Therefore, from these observations we propose that the combination of precipitation and temperature distribution on the Niesen is likely responsible for altitudinal distribution of the denudation rates. Temperature-dependent processes such as frost cracking will be stronger in the highest part of the topography, therefore promoting the production of detrital materials in the highest basins. Moreover, this basins being affected by stronger annual precipitation and consequently more discharge, erosion will be also promoted through both increased runoff/transport capacity in channels and higher slip rates of landslides (e.g., Schürch et al., 2006). Accordingly, while the patterns of erosion are strongly controlled by the tectonic architecture of the underlying bedrock (dip slope versus non-dip slope), the rates at which erosion has occurred appears to be substantially modulated by temperature as well as rain. This supports previous statements (Gilbert, 1877; Hack, 1960) that topographic form, rocks, and erosion rates may be highly coupled such that feedbacks cause rates to be similar in accordance with the different processes that lower the landscapes with different rock type or orientation.

\section{Conclusions}

Precipitation, lithology, mean slopes, rock uplift, landslides and past glaciations have been proven to be the central parameters controlling landscape development in mountainous settings. Our study site, located at Niesen, offers an alternative perspective into landscape evolution studies, such that contrasting development of the hillslopechannel system may largely be controlled by the dip orientation of the underlying bedrock. Since mean ${ }^{10} \mathrm{Be}$ denudation rates are nearly identical on both flanks, we are able to say that landscape form has no predictive ability to infer differences in the evolutionary state of a landscape, in the sense that denudation rates are not a function 
of whether the landscape at Niesen is close or far from an erosional steady state. Indeed, patterns in ${ }^{10} \mathrm{Be}$-based denudation rates scale with elevation and we suggest reflect orographic conditions (supported with climate data) rather than potential contrasts in evolutionary states. However, field observations revealed visible similarities in channel morphologies of adjacent streams but distinct differences on opposite facing flanks. Quantitative morphometric analysis revealed differences between dip and non-dip flanks related to contrasts in the relative prominence of channelized and hillslope processes. In turn, the prominence of these processes is controlled by the bedrock orientation in relation to the topographic slope. Channelized processes on the non-dip slope Frutigen side have promoted the formation of steep and closely spaced basins with high concavity and high channel steepnesses. In contrast, the dominance of hillslope sediment transport processes on the dip slope Diemtigen flank has resulted in a landscape with an irregular yet smooth topography, characterized by low channel concavities, low hillslope gradients and decreased channel steepness. Our results thus indicate that the dip-orientation of the bedrock has the potential to promote channelized and hillslope processes to contrasting degrees and has ultimately resulted in the creation of two distinctly different landscapes capable of removing mass at the same rate. We thus conclude that while the patterns of erosion are strongly controlled by the tectonic architecture of the underlying bedrock (dip slope versus non-dip slope), the rates at which erosion has occurred appears to be substantially modulated by frostinduced processes as well as orographic rain. Also, the results of this study suggest that while local hillslope and channel processes appear to compete in the evolution of local relief production (smoothing versus incising), frost processes and precipitation may lead to relief production at a larger scale, consistent with ${ }^{10} \mathrm{Be}$-based catchmentaveraged denudation rates. Although we lack the required dataset to solve this scale problem, we note that this paper supports previous studies by Gilbert (1877) and Hack (1960) that imply that feedbacks between topographic form, erosional processes and erosion rates conspire to make landscapes with different topographic forms, but similar erosion rates if averaged over several basins.

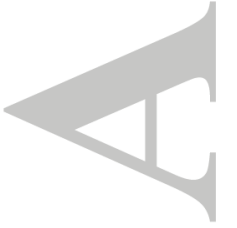




\section{Acknowledgements}

Research has been funded through a SNF TopoEurope grant No 20T021-120464 awarded to Schlunegger. Technical support in the field and in the lab by D. Rieke Zapp and T. Bekaddour are kindly acknowledged. Constructive comments by the Associate Editor, P. Valla and an anonymous reviewer are kindly acknowledged.

\section{References}

Aalto R, Dunne T, Guyot JL. 2006. Geomorphic controls on Andean denudation rates. Journal of Geology 114: 85-99.

Ackermann A. 1986. Le Flysch de la nappe du Niesen. Eclogae Geologicae Helvetiae 79: 641-684.

Akçar N. 2006. Paleoglacial records from the Black Sea area of the Turkey field and dating evidence. PhD dissertation, University of Bern, Switzerland.

Akçar N, Deline P, Ivy-Ochs S, Alfinov V, Hajdas I, Kubik P, Christl M, Sclüchter C. 2012. The AD 1717 rock avalanche deposits in the upper Ferret Valley (Italy): a dating approach with cosmogenic ${ }^{10} \mathrm{Be}$. Journal of Quaternary Science 27: 383-392.

Anderson RS. 1994. Evolution of the Santa Cruz Mountains, California, through tectonic growth and geomorphic decay. Journal of Geophysical Research 99: 20161-20179.

Auer M. 2003. Regionalisierung von Schneeparametern: Eine Methode zur Darstellung von Schneeparametern im Relief. Universität Bern, 97pp.

Baeriswyl P.A., Rebetez M. 1997. Regionalization of precipitation in Switzerland by means of principal component analysis. Theoretical and Applied Climatology 58: 31-41.

Balco G, Stone J, Lifton N, Dunai T. 2008. A simple, internally consistent, and easily accessible means of calculating surface exposure ages and erosion rates from Be10 and Al-26 measurements. Quaternary Geochronology 3: 174-195.

Bini A, Buoncristiani J-F, Couterrand S, Ellwanger D, Felber M, Florineth D, Graf HR, Keller 0, Kelly M, Schlüchter C, Schoeneich P. 2009. Die Schweiz während des letzteiszeitlichen Maximums (LGM) 1:500`000. Bundesamt für Landestopografie Swisstopo.

Binnie SA, Phillips WM, Summerfield MA, Fifield LK. 2007. Tectonic uplift, threshold hillslopes, and denudation rates in a developing mountain range. Geology 35: 743746.

Bishop P, Goldrick G. 2010. Lithology and the evolution of bedrock rivers in postorogenic settings: Constraints from the high elevation passive continental margin of SE Australia. Geological Society of London Special Publications, 346 pp.

Bovis, M., Jacob, M. 1999. The role of debris supply conditions in predicting debris flow activity. Earth Surface Processes and Landforms 24: 1039-1054.

Brardinoni F, Church M, Simoni A, Macconi P. 2012. Lithologic and glacially conditioned controls on regional debris-flow sediment dynamics. Geology 40: 455-458.

Brocard GY, Van Der Beek PA. 2006. Influence on incision rate, rock strength, and bedload supply on bedrock river gradients and valley-flat widths. Field-based evidence and calibration from western Alpine rivers (South-East France). In Tectonics, climate, and landscape evolution, Willett SD, Hovius N, Brandon MT, Fisher DM (eds). GSA Special Paper 398: 101-125. 
Caduff R. 2008. Geologie und Oberflächenmorphologie als Steuerungsfaktoren rezenter Massenbewegungen. Unpublished Ms thesis, University of Bern, Bern, 99 p.

Caron C, Homewood P, Wildi W. 1989. The Original Swiss Flysch: A Reappraisal of the Type Deposits in the Swiss Prealps. Science 26: 1-45.

Chmeleff J. von Blanckenburg F, Kossert K, Jacob D. 2010. Determination of the ${ }^{10}$ Be halflife by multicollector ICP-MS and liquid scintillation counting. Nuclear Instruments and Methods in Physics Research 268: 192-199.

Delunel R, van der Beek P, Carcaillet J, Borulès D, Valla PG. 2011. Frost-cracking control on catchment denudation rates: Insights from in situ produced ${ }^{10} \mathrm{Be}$ concentrations in stream sediments (Ecrins-Pelvoux massif, French western Alps). Earth and Planetary Science Letters 293: 72-83.

Delunel R, van der Beek P, Bourlès D, Carcaillet J, Schlunegger F. 2013. Transient sediment supply in a high-altitude Alpine environment evidenced through a ${ }^{10} \mathrm{Be}$ budget of the Etages catchment (French western Alps). Earth Surface Processes and Landforms, doi:10.1002/esp.3494.

DiBiase RA, Whipple KX, Heimsath AM, Ouimet WB. 2010. Landscape form and millennial erosion rates in the San Gabriel Mountains, CA. Earth and Planetary Science Letters 289: 134-144.

Dunai TJ. 2010. Cosmogenic Nuclides: Principles, Concepts and Applications in the Earth Surface Sciences, 1st edition. Cambridge University Press, Cambridge, 198 p.

Dunai TJ. 2000. Scaling factors for production rates of in situ produced cosmogenic nuclides: a critical re-evaluation. Earth and Planetary Science Letters 17: 157-169.

Fischli M. 2010. Geologisch-geomorphologische Analyse der Oberflächenprozesse an der Niesenkette. Unpublished Ms thesis, University of Bern, Bern, 109 p.

Flint JJ. 1974. Stream gradient as a function of order, magnitude, and discharge. Water Resource Research 10: 969-973.

Frei C., Schär C. 1998. A precipitation climatology of the Alps from high-resolution raingauge observations. International Journal of Climatology 18: 873-900.

Gilbert G. K. 1877. Geology of the Henry Mountains, U. S. Geographical and Geological Survey of the Rocky Mountain Region: Washington D.C. U.S. Government Printing Office, $160 \mathrm{p}$.

Glotzbach C., van der Beek P., Carcaillet J., Delunel R. 2013. Deciphering the driving forces of erosion rates on millennial to million-year timescales in glacially impacted landscapes: An example from the Western Alps. Journal of Geophysical Research Earth Surface 118, doi:10.1002/jgrf.20107.

Hack, J.T. 1960. Interpretation of erosional topography in humid temperate regions. American Journal of Science 258: 80-97.

Hales T.C., Roering J.J. 2007. Climatic controls on frost cracking and implications for the evolution of bedrock landscapes. Journal of Geophysical Research 112, F02033.

Harvey AM. 2001. Coupling between hillslopes and channels in upland fluvial systems: implications for landscape sensitivity, illustrated from the Howgill Fells, northwest England. Catena 42: 225-250.

Harvey AM. 2002. Effective timescales of coupling within fluvial systems. Geomorphology 44: 175-201.

Harvey AM. 2012. The coupling status of alluvial fans and debris cone: a review and synthesis. Earth Surface Processes and Landforms 37: 64-76.

Kelly M, Buoncristiani J, Schlüchter C. 2004. A reconstruction of the Last Glacial Maximum (LGM) ice-surface geometry in the western Swiss Alps and contiguous Alpine regions in Italy and France. Eclogae Geologicae Helvetiae 97: 57-75. 
Kober F, Ivy-Ochs S, Schlunegger F, Baur H, Kubik PW, Wieler R. 2007. Denudation rates and a topography-driven rainfall threshold in northern Chile: Multiple cosmogenic nuclide data and sediment yield budgets. Geomorphology 83: 97-120.

Kober F, Hippe K, Salcher B, Ivy-Ochs S, Kubik PW, Wacker L, Hählen N. 2012. Debrisflow-dependent variation of cosmogenically derived catchment-wide denudation rates. Geology 40: 935-938.

Kohl CP, Nishiizumi K. 1992. Chemical isolation of quartz for measurement of in-situ produced cosmogenic nuclides. Geochimica et Cosmochimica Acta 56: 3583-3587.

Korschinek, G., Bergmaier, A., Faestermann, T., Gerstmann, U.C., Knie, K., Rugel, G., Wallner, A., Dillmann, I., Dollinger, G., von Gostomski, Ch.L., Kossert, K., Maiti, M., Poutivtsev, M., Remmert, A. 2010. A new value for the half-life of ${ }^{10}$ Be by heavyion elastic recoil detection and liquid scintillation counting. Nuclear Instruments and Methods in Physics Research Section B: Beam Interactions with Materials and Atoms 268: 187-191.

Korup 0. 2006. Rock-slope failure and the river long profile. Geology 34: 45-48.

Korup 0, Schlunegger F. 2009. Rock-type control on erosion induced uplift, eastern Swiss Alps. Earth and Planetary Science Letters 278: 278-285.

Kubik PW, Christl M. 2010. ${ }^{10} \mathrm{Be}$ and ${ }^{26} \mathrm{Al}$ measurements at the Zurich $6 \mathrm{MV}$ Tandem AMS facility. Nuclear Instruments and Methods in Physics Research Section B 268: 880-883.

Kühni A, Pfiffner OA. 2001. The relief of the Swiss Alps and adjacent areas and its relation to lithology and structure: Topographic analysis from a 250-m DEM. Geomorphology 41: 285-307.

Lal D. 1991. Cosmic ray labeling of erosion surfaces: In situ nuclide production rates and erosion models. Earth and Planetary Science Letters 104: 424-439.

Lague D, Davy P. 2003. Constraints on the long-term colluvial erosion law by analyzing slope-area relationships at various tectonic uplift rates in the Siwaliks Hills (Nepal). Journal of Geophysical Research 108(B2), 2129.

Matmon A, Bierman PR, Larsen J, Southworth S, Pavich M, Caffee M. 2003. Temporally and spatially uniform rates of erosion in the southern Appalachian Great Smoky Mountains. Geology 31: 155-158.

Montgomery DR, Dietrich W E. 1992. Channel initiation and the problem of landscape scale. Science 255: 826-830.

Montgomery DR. 2001. Slope distribution, threshold hillslopes, and steady-state topography. American Journal of Science 301: 432-454.

Niemi NA, Oskin M, Burbank DW, Heimsath AM, Gabet EJ. 2005. Effects of bedrock landslides on cosmogenically determined erosion rates. Earth and Planetary Science Letters 237: 480-498.

Norton KP, von Blanckenburg F, Schlunegger F, Schwab M, Kubik P. 2008. Cosmogenic nuclide-based investigation of spatial erosion and hillslope channel coupling in the transient foreland of the Swiss Alps. Geomorphology 95: 474-486.

Norton KP, Vanacker V. 2009. Effects of terrain smoothing on topographic shielding correction factors for cosmogenic nuclide- derived estimates of basin-averaged denudation rates. Earth Surface Processes and Landforms 34: 145-154.

Norton KP, Abbühl LM, Schlunegger F. 2010(a) Glacial conditioning as an erosional driving force in the Central Alps. Geology 38: 655-658.

Norton KP, von Blanckenburg F, Kubik PW. 2010(b) Cosmogenic nuclide-derived rates of diffusive and episodic erosion in the glacially sculpted upper Rhone Valley, Swiss Alps. Earth Surface Processes and Landforms 35: 651-662. 
Norton KP, von Blanckenburg F, DiBiase R, Schlunegger F, Kubik PW. 2011. Cosmogenic ${ }^{10}$ Be-derived denudation rates of the Eastern and Southern European Alps. International Journal of Earth Sciences 100: 1163-1179.

Ouimet WB, Whipple KX, Granger DE. 2009. Beyond threshold hillslopes: Channel adjustment to base-level fall in tectonically active mountain ranges. Geology 37: 579-582.

Perron JT, Kirchner J, Dietrich WE. 2009. Formation of evenly spaced ridges and valleys. Nature 460: 502-505.

Palumbo L, Hetzel R, Tao M, Li X. 2009. Topographic and lithologic control on catchment-wide denudation rates derived from cosmogenic ${ }^{10} \mathrm{Be}$ in two mountain ranges at the margin of NE Tibet. Geomorphology 117: 130-142.

Roering JJ, Kirchner JW, Dietrich WE. 2005. Characterizing structural and lithologic controls on deep-seated landsliding: Implications for topographic relief and landscape evolution in the Orogen Coast Range, USA. Geological Society of America Bulletin 117: 654-668.

Safran EB, Bierman PR, Aalto R, Dunne T, Whipple K, Caffee M. 2005. Erosion rates driven by channel network incision in the Bolivian Andes. Earth Surface Processes and Landforms 30: 1007-1024.

Simpson G, F. 2003. Topographic evolution and morphology of surfaces evolving in response to coupled fluvial and hillslope sediment transport. Journal of Geophysical Research 108: 1-16.

Schlatter A, Schneider D, Geiger A, Kahle HG. 2005. Recent vertical movements from precise levelling in the vicinity of the city of Basel, Switzerland. International Journal of Earth Sciences 94: 507-514.

Savi S, Norton KP, Picotti V, Brardinoni F, Akçar N, Kubik PW, Delunel R, Schlunegger F. 2013. Effects of sediment mixing on ${ }^{10} \mathrm{Be}$ concentrations in the Zielbach catchment, central-eastern Italian Alps. Quaternary Geochronology, in press.

Schlunegger, F. 2002. Impact of hillslope derived sediment supply on drainage basin development in small watersheds at the northern border of the central Alps of Switzerland. Geomorphology 46: 285-305.

Schlunegger, F, Norton KP, Zeilinger G. 2011. Climate forcing on channel profiles in the Eastern Cordillera of the Coroico region, Bolivia. The Journal of Geology 119, 97 107.

Schlunegger F, Norton KP, Caduff R. 2013. Hillslope processes in temperate environments. In Treatise in Geomorphology, Vol. 3: Mountain and Hillslope Geomorphology, Marston R, Stoffel M. (eds). Elsevier, London, in press.

Schlunegger, F., and Norton, KP 2013. Water versus ice: The competing roles of modern climate and Plesitocene glacial erosion in the Central Alps of Switzerland. Tectonophysics 606, 370-381.

Schürch P. Densmore AL, McArdell BW, Molnar P. 2006. The influence of landsliding on sediment supply and channel change in a steep mountain catchment. Geomorphology 78: 222-235.

Schwab M, Schlunegger F, Schneider H, Stöckli G, Rieke-Zapp D. 2009. Contrasting sediment flux in Val Lumnezia (Graubünden, Eastern Swiss Alps), and implications for landscape development. Swiss Journal of Geosciences 102: 211-222.

Stone J., 2000. Air pressure and cosmogenic isotope production. Journal of Geophysical Research 105: 753-759.

Strahler AN. 1954. Statistical Analysis in Geomorphic Research. The journal of Geology 62: 1-25. 
Tucker GE, Slingerland R. 1996. Predicting sediment flux from fold and thrust belts. Basin Research 8: 329-349.

Tucker GE, Slingerland R. 1997. Drainage basin response to climate change. Water Resources Research 33: 2031-2047.

Van den Berg F, Schlunegger F, Akçar N, Kubik P. 2012. ${ }^{10}$ Be-derived assessment of accelerated erosion in a glacially conditioned inner gorge, Entlebuch, Central Alps of Switzerland. Earth Surface Processes and Landforms 37: 1176-1188.

van der Beek P, Bourbon P. 2008. A quantification of the glacial imprint on relief development in the French Western Alps. Geomorphology 97: 52-72

van der Beek P, Braun J. 1998. Numerical modelling of landscape evolution on geological time-scales: a parameter analysis and comparison with the south-eastern highlands of Australia. Basin Research 10: 49-68.von Blanckenburg, F. 2005. The control mechanisms of erosion and weathering at basin scale from cosmogenic nuclides in river sediment. Earth and Planetary Science Letters 234: 462-479.

Weidmann M, Homewood P, Caron C, Baud A. 1976. Rehabilitation de la "Zone Submediane" des Preralpes. Eclogae Geologicae Helvetiae 69: 265-277.

Whipple KX. 2004. Bedrock Rivers and the geomorphology of active orogens. Annual Review Earth Planetary Science Letters 32: 151-185

Wittmann H, von Blanckenburg F, Kruesmann T, Norton KP, Kubik PW. 2007. Relation between rock uplift and denudation from cosmogenic nuclides in river sediment in the Central Alps of Switzerland. Journal of Geophysical Research 112: F04010.

Wobus C, Whipple KX., Kirby E, Snyder N, Johnson J, Spyropolou K, Crosby B, Sheehan D. 2006. Tectonics from topography: procedures, promise, and pitfalls. In Tectonics, climate, and landscape evolution, Willett SD, Hovius N, Brandon MT, Fisher DM (eds). GSA Special Paper 398: 55-74.

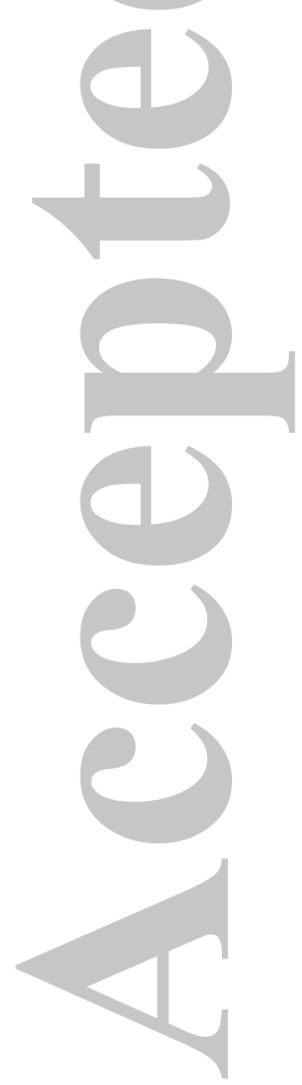

This article is protected by copyright. All rights reserved. 


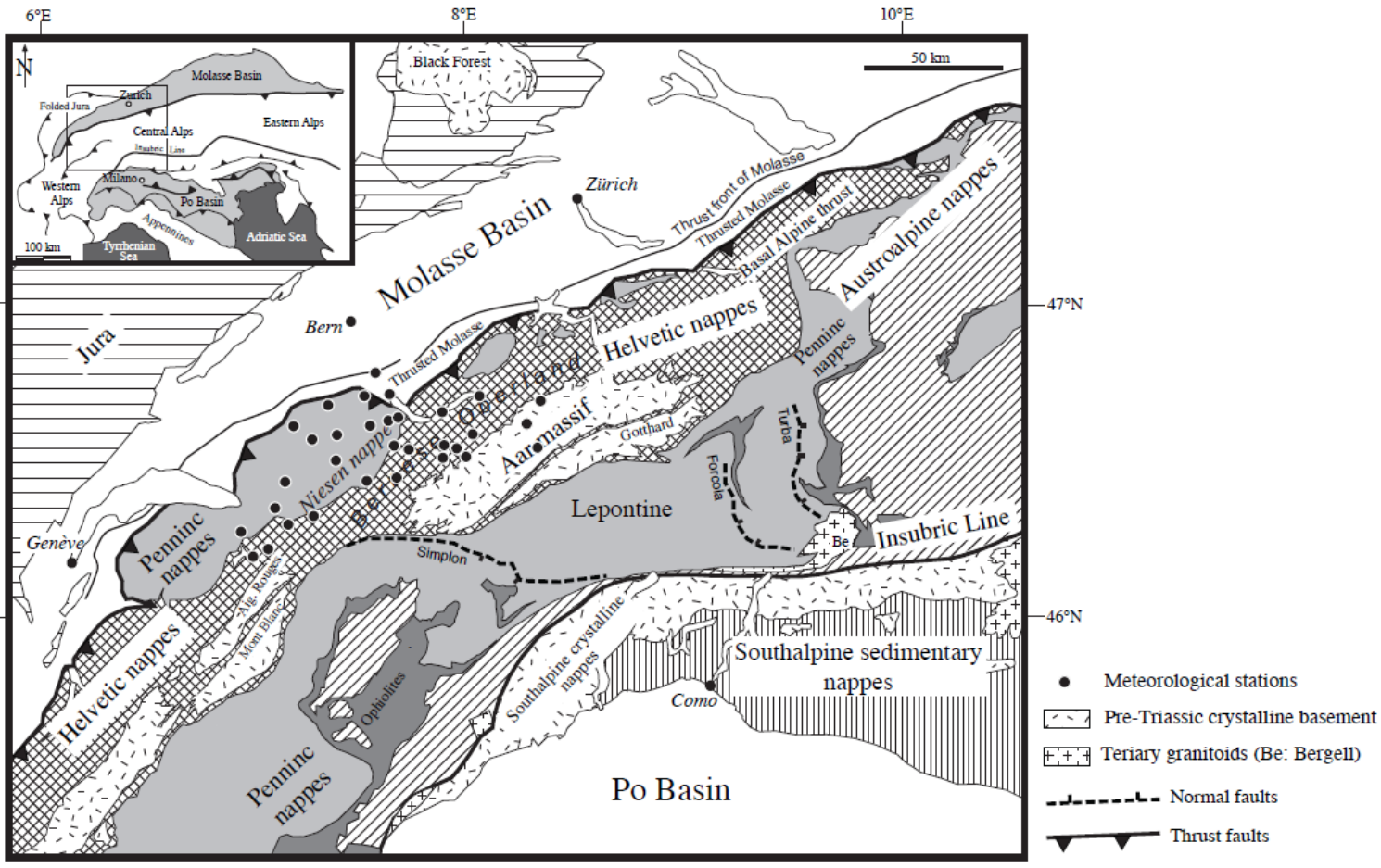

Figure 1. (A) General overview of the geographic and tectonic setting of the study site within the Central European Alps (Modified after Kühni and Pfiffner, 2001). The figure also shows the sites of which climate parameters, measured by MeteoSwiss, have been used in this paper (Table 1). 


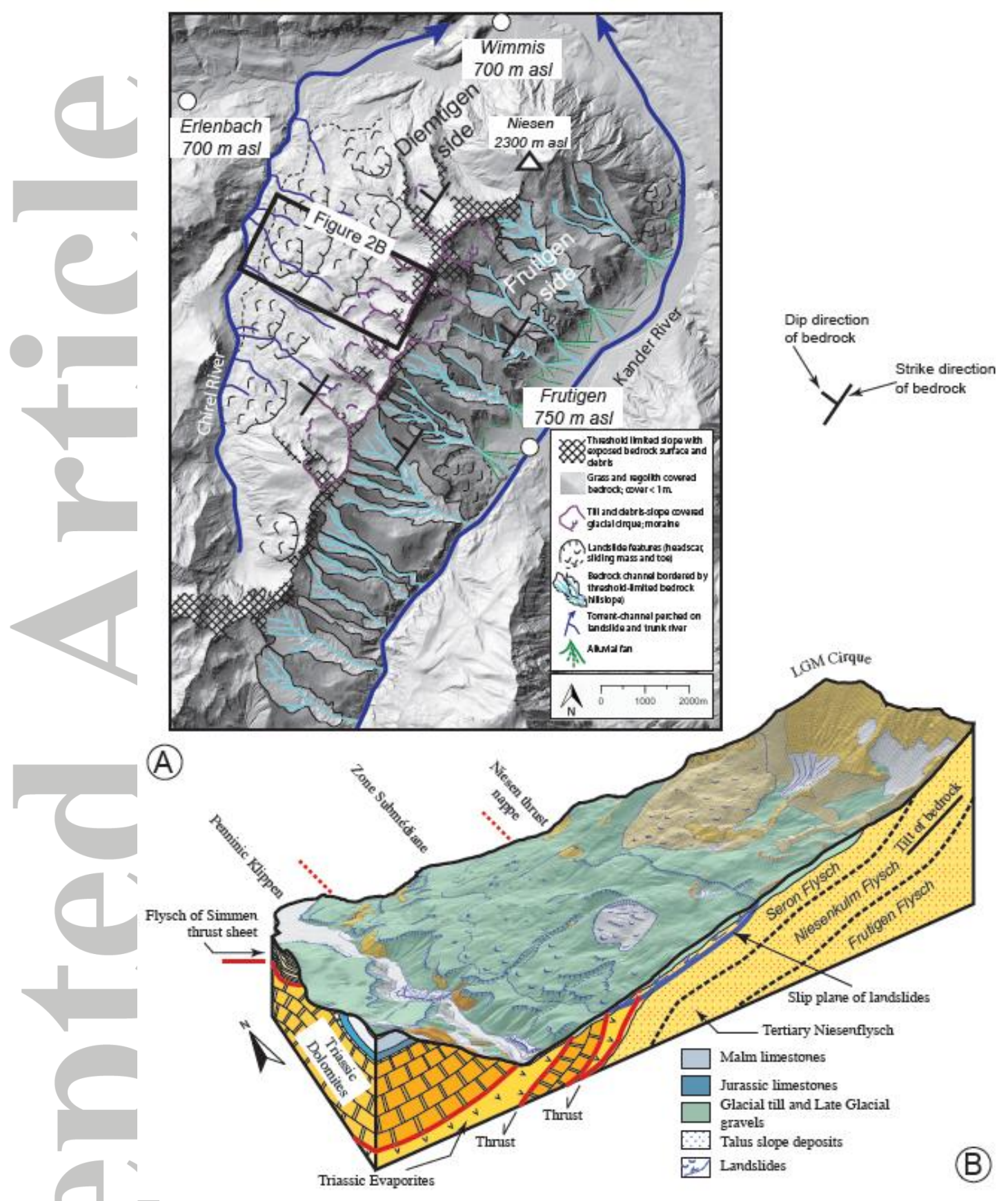

Figure 2. A) Hillshade DEM of the Niesen mountain range and drainage network and geomorphological map of the region. The geomorphological details of the Diemtigen side have been taken from Caduff (2008). Fischli (2010) mapped bedrock channels and threshold limited hillslopes (Schlunegger et al., 2013) on the northern part of the Frutigen side that we have adapted in this paper. The geomorphological information from the remaining sectors is based on own observations. B) 3-D view of the geological and geomorphological architecture of the dip slope Diemtigen side (modified after $\begin{array}{llllll}\text { Schlunegger et } & \text { al., 2013). DEM } & \text { (C) } 2012 \text { Swisstopo }\end{array}$ 


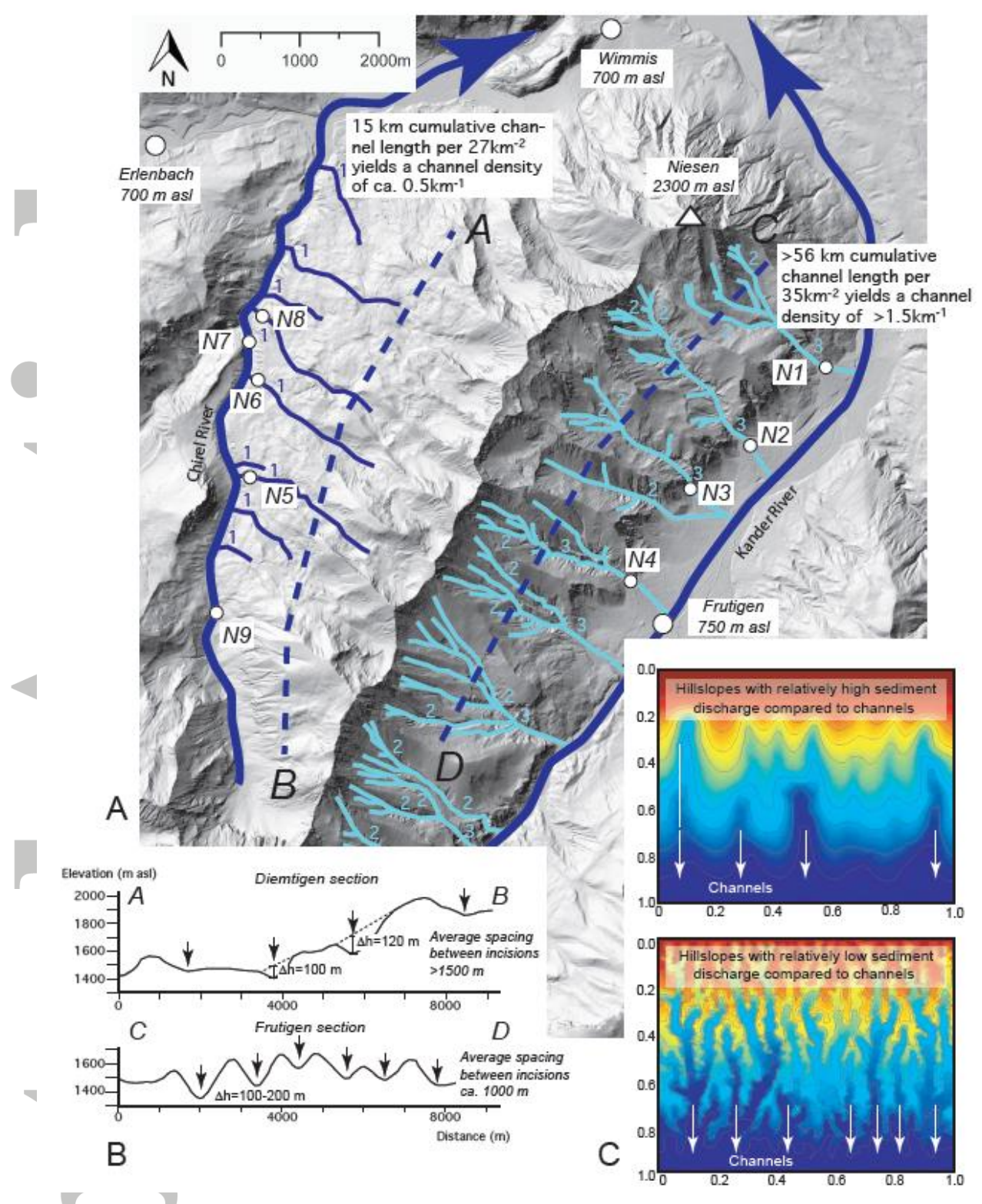

Figure 3. Hillshade DEM of the Niesen mountain range, drainage network, drainage density, Strahler order of tributary streams and sites that have been collected for ${ }^{10} \mathrm{Be}$ analyses. B) topographic sections across the non-dip slope Frutigen (SE) and dip slop Diemtigen (NW) side, and C) results of numerical model that illustrate effects related to differences in the relative importance of sediment transport on hillslopes and in channels. The upper diagram shows the model topography where hillslope sediment transport has been efficient, resulting in a smooth landscape with a low channel density, which corresponds to the Diemtigen side where landslides are abundant. The lower diagram illustrates the model topography where hillslopes are relatively stable, thus allowing channels to develop a dense network of branched channels. This corresponds to the Frutigen side, where landslides are few, thus allowing channels to erode the landscape more deeply. Models are not to scale and are modified after Simpson and Schlunegger (2003). DEM (C) 2012 Swisstopo 


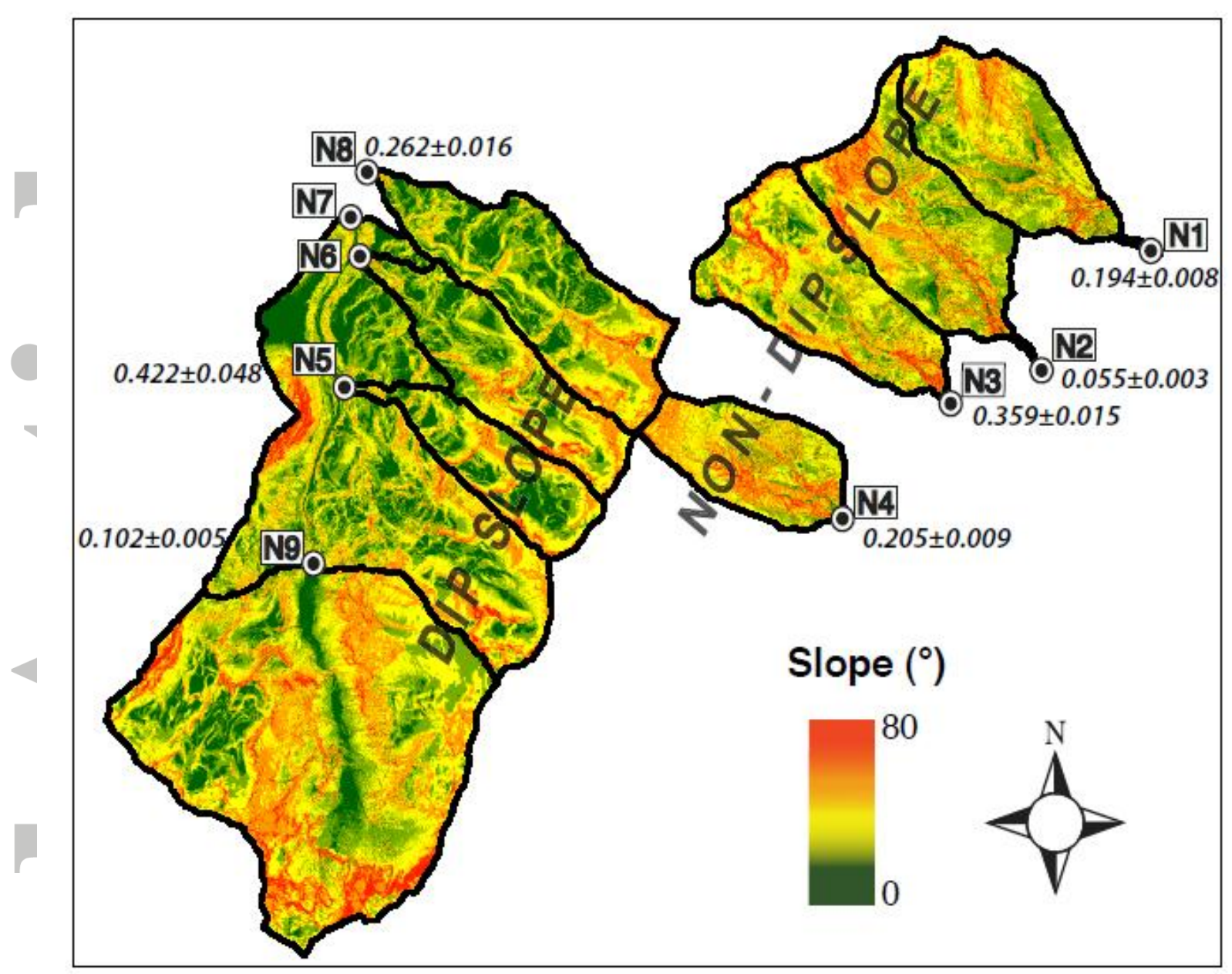

Figure 4. Distribution of mean basin hillslope angles for sampled catchments illustrating differences in channel and hillslope morphology for dip slope and non-dip slope settings. The figure also shows the pattern of ${ }^{10} \mathrm{Be}$ basin-averaged denudation rates (italic numbers in mm/yr). Catchments from the Frutigen flank (N1 - N4) are considerably steeper than those from the Diemtigen side (N5 - N9). DEM (C) 2012 Swisstopo 

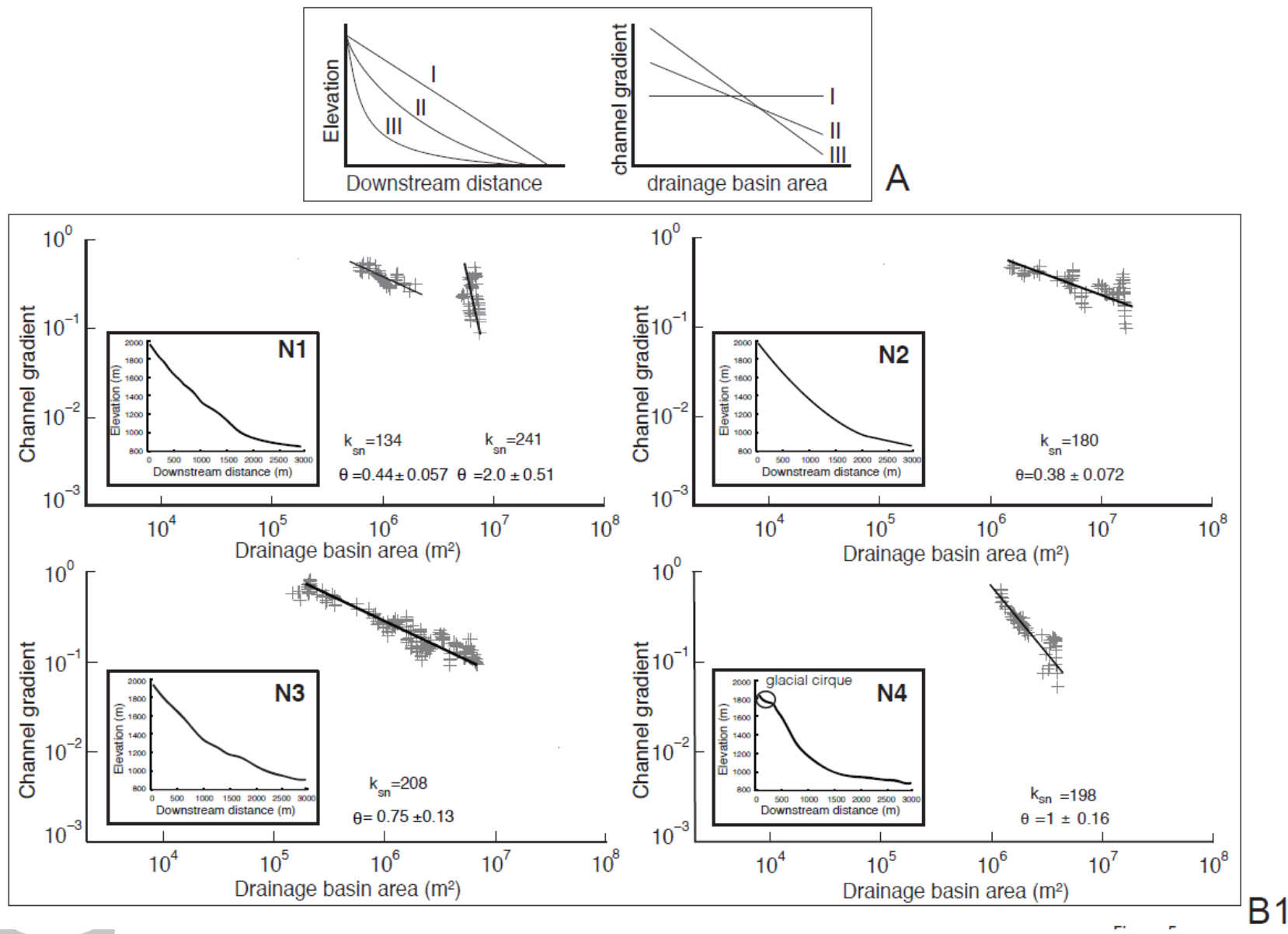

Figure 5. A) Conceptual diagrams illustrating how steepness and concavity values can be used to infer the relative erosional efficiency of streams, where stream I has not eroded an originally included plane, while erosion by stream II and III has been moderately and very efficient, respectively. As a result, concavity and steepness values of stream I will be much lower than those of stream II. The channel of stream III will have the highest concavity and steepness values. 


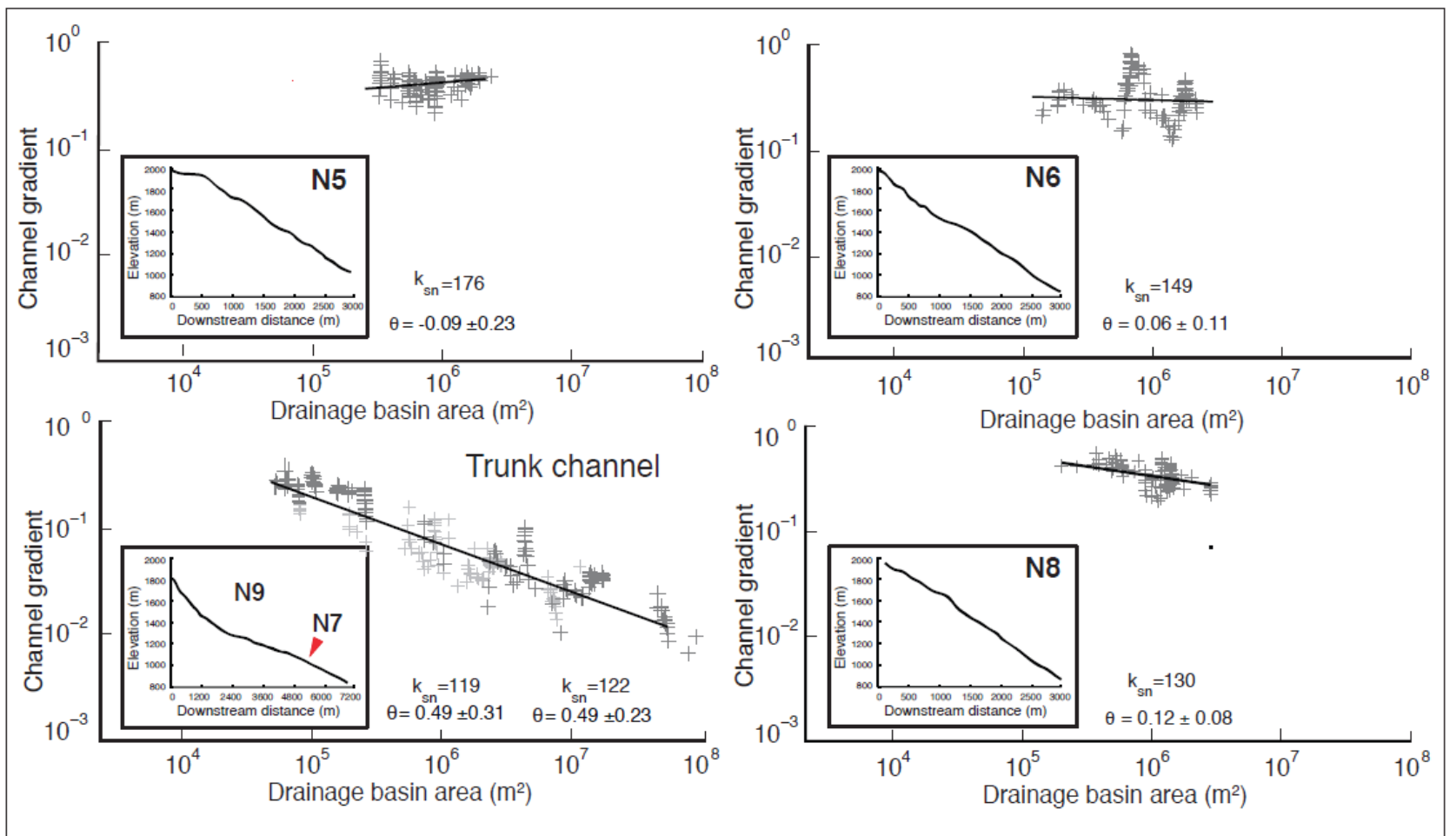

Figure 5. B) Log-log plot of slope-area relationships and corresponding longitudinal stream profile insets for all sampled catchments at the Niesen. Plots represent portions of the channel network that are exclusive to a fluvial slope-area regime and regression lines help emphasize differences in concavity indicies $(\theta)$ of the Frutigen (N1-N4) (B1) and Diemtigen (N5-N9) flanks (B2). N9 (dark grey) and N7 (light grey) were plotted together since they are upstream and downstream sampling locations on the same trunk stream. All channel steepness values $(K s n)$ were normalized to a reference concavity of 0.45 . Elevation is $m$ a.s.l. 


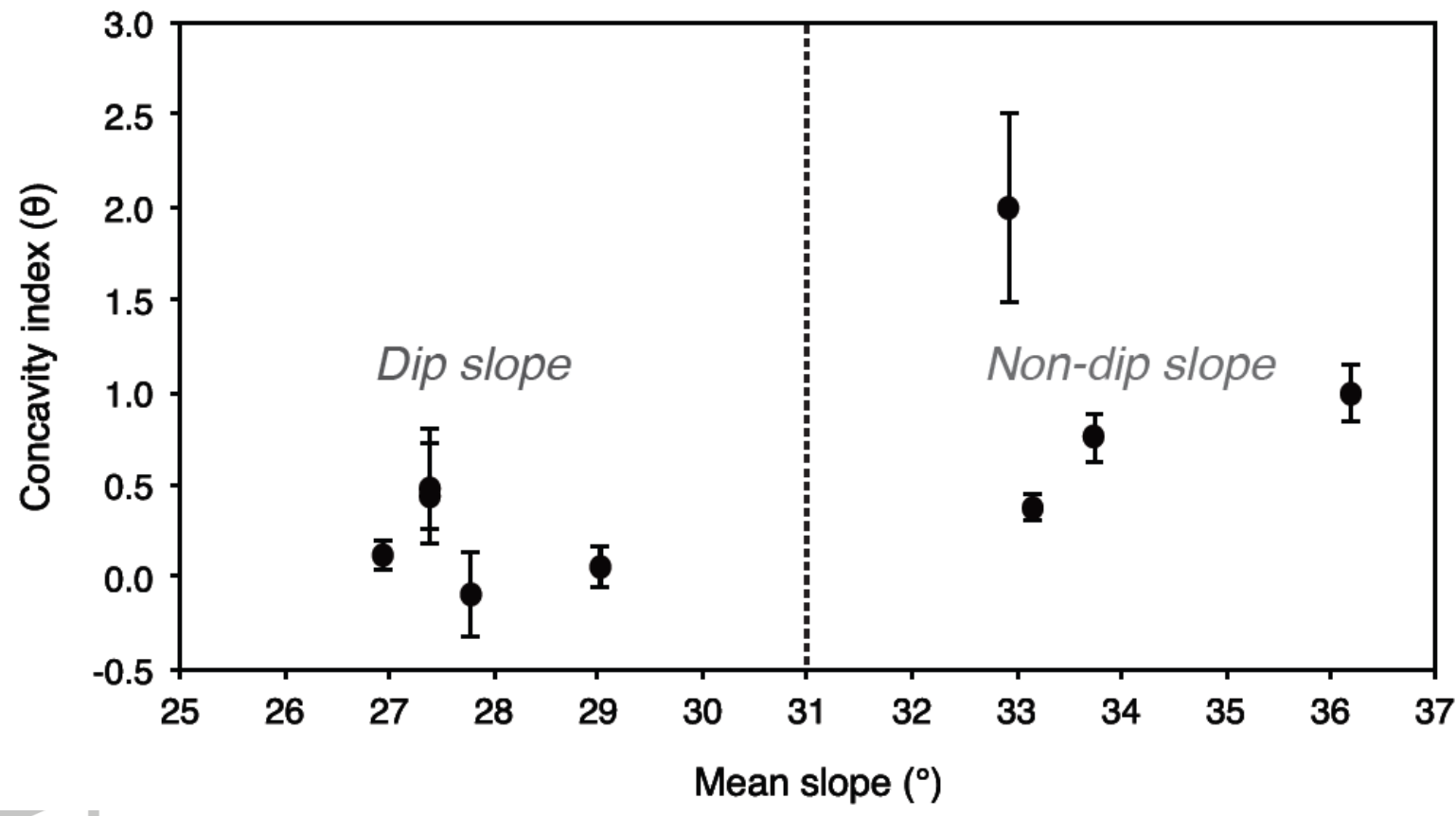

Figure 6. Plot showing dip slope and non-dip slope flanks partitioned by mean basin slope. Dotted line separates results based on bedrock inclination. Concavity and mean slope have a weak, yet positive relationship with $\mathrm{R}^{2}=0.363$. 

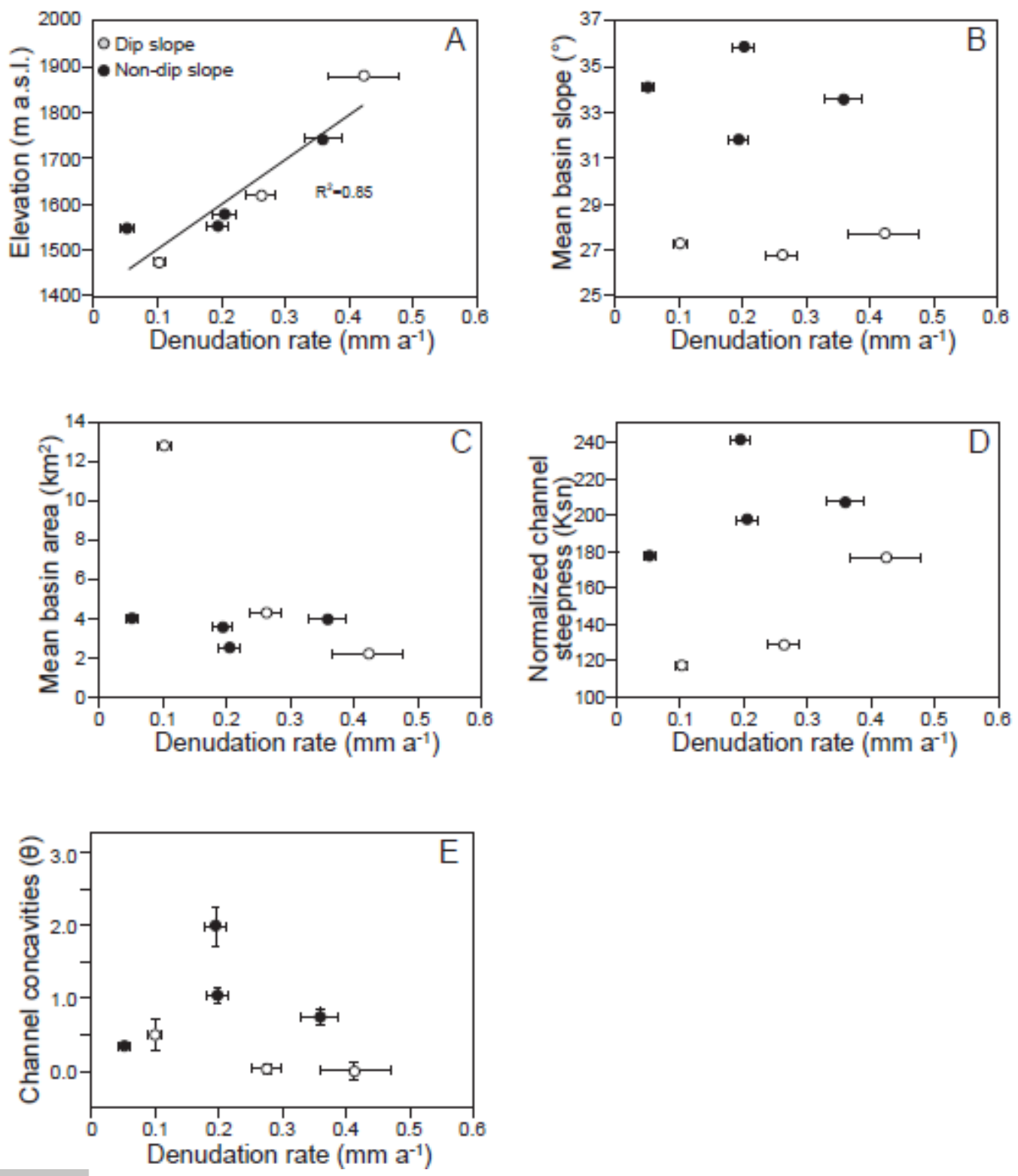

Figure 7. Relationship between ${ }^{10} \mathrm{Be}$ basin-averaged denudation rates with (A) mean basin elevation (or altitude), (B) mean basin slope, (C) basin area, (D) normalized channel steepness and (E) concavity index. Note that relative uncertainties associated with elevation, slope and drainage areas are calculated as Standard Error of the Mean (SEM) and are therefore systematically smaller than $1 \%$ due to the large number of pixel in each basin.

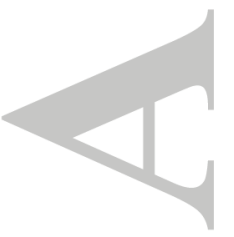

This article is protected by copyright. All rights reserved. 

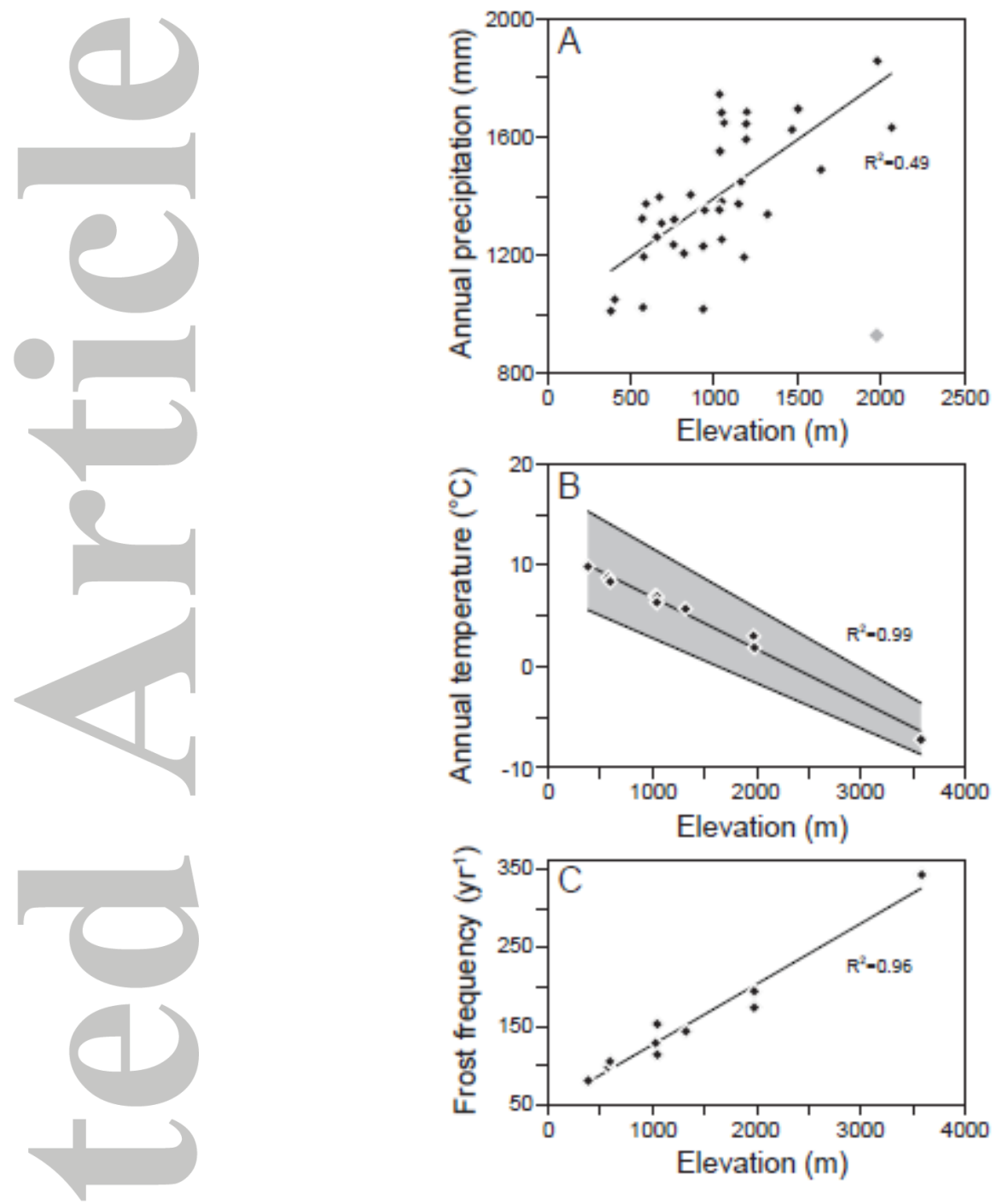

Figure 8. Climate data for the region surrounding the Niesen range illustrating A) orographic controls on precipitation rates (with one outlier represented in grey, Le Moléson, located on the southwestern margin of the northern border of the Bernese Oberland, Figure 1 and Table 1), B) mean annual temperatures as a function of altitude (note that the lower and upper bounds of the shaded area are produced from the linear interpolation of the minimum and maximum annual air temperature calculated for each station), and C) the frost frequency. All data were obtained from MeteoSwiss and are presented in Table 1.

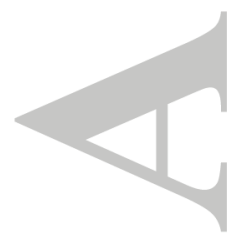




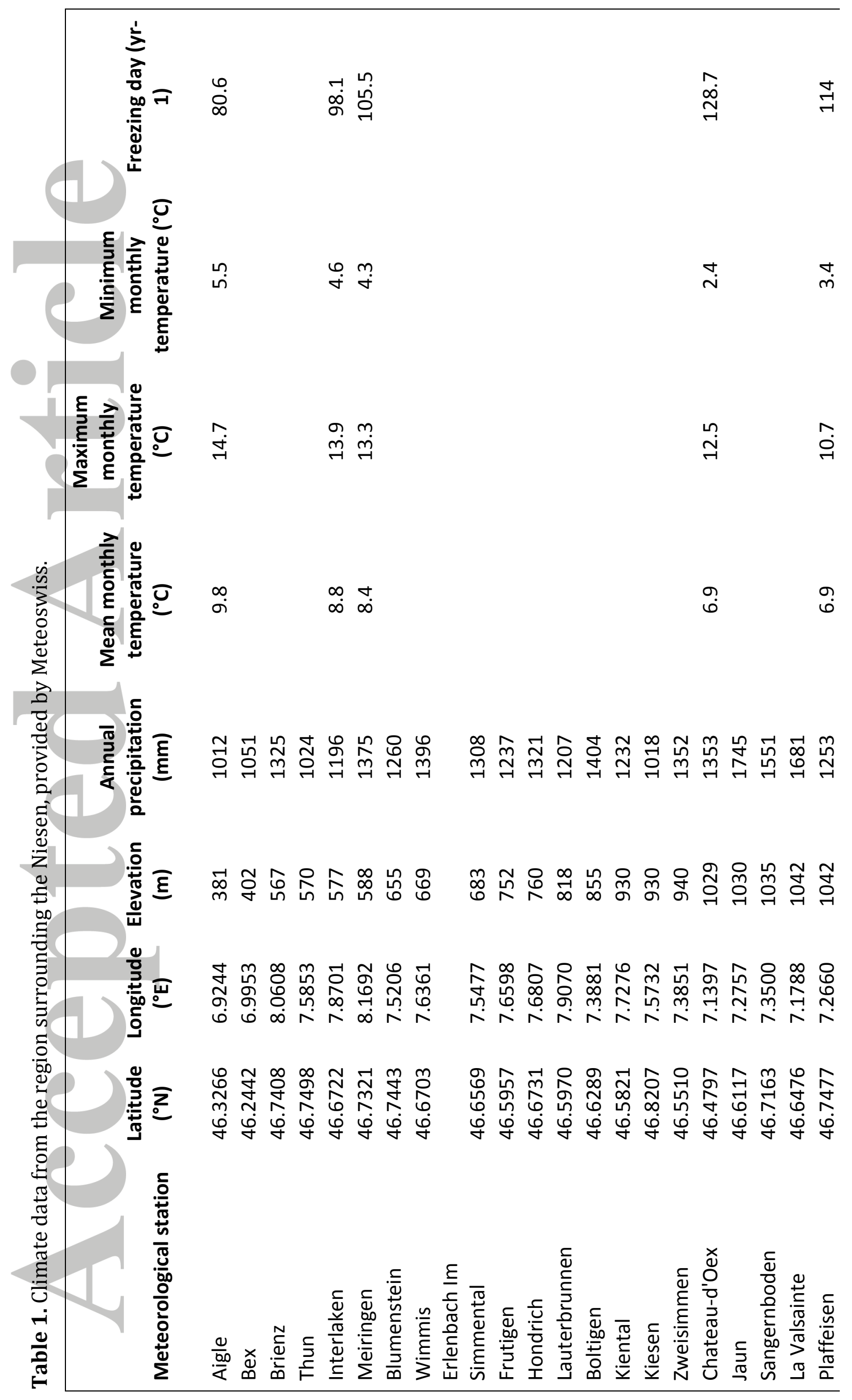

This article is protected by copyright. All rights reserved. 

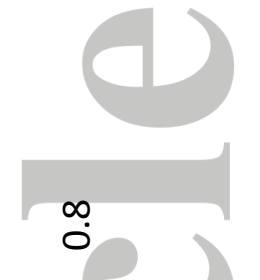

$\stackrel{\infty}{+}$

กี่

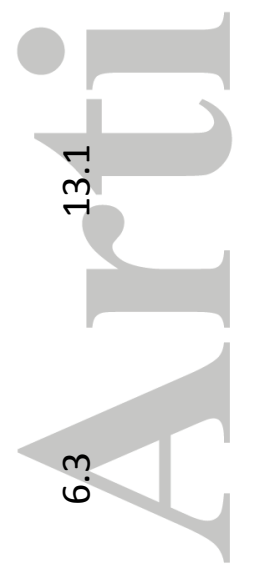

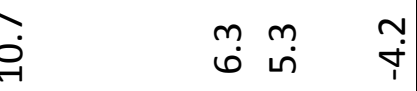

$\hat{\text { i }}$

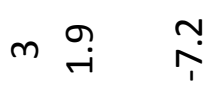

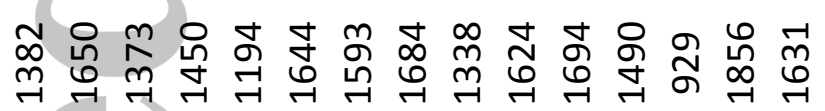

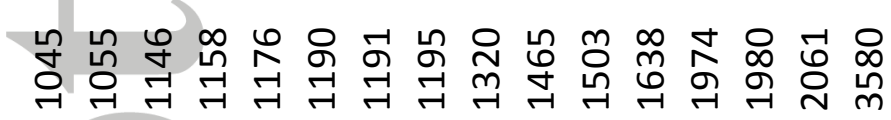

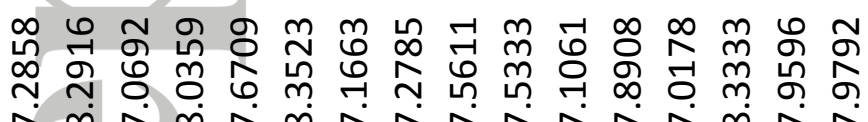

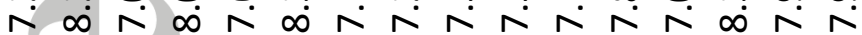

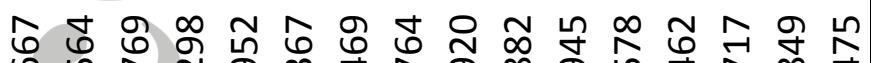

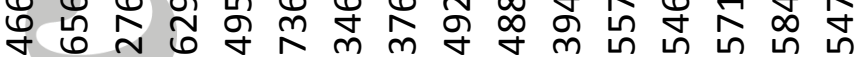

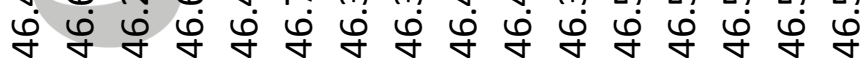

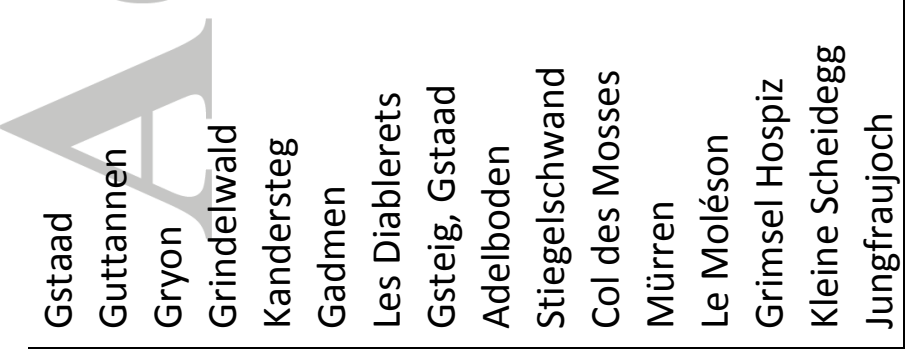

This article is protected by copyright. All rights reserved. 


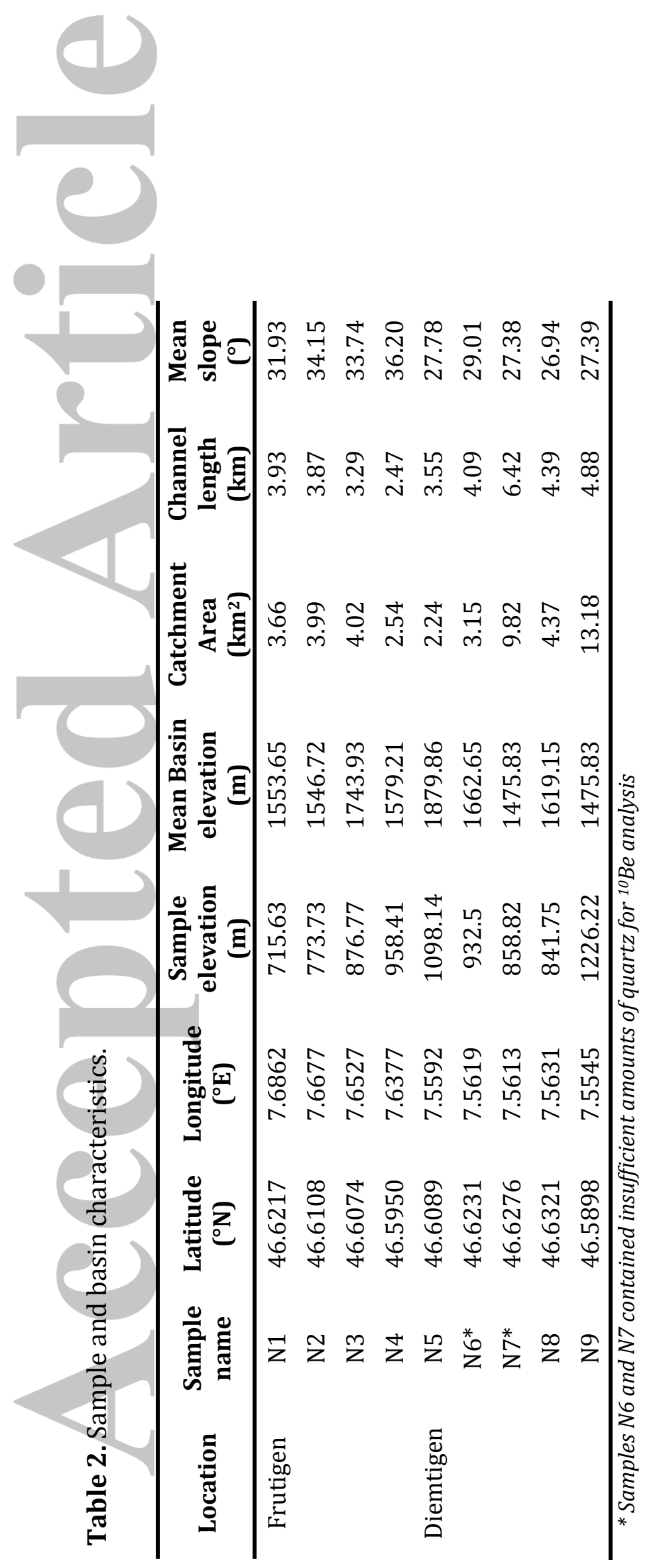

This article is protected by copyright. All rights reserved. 


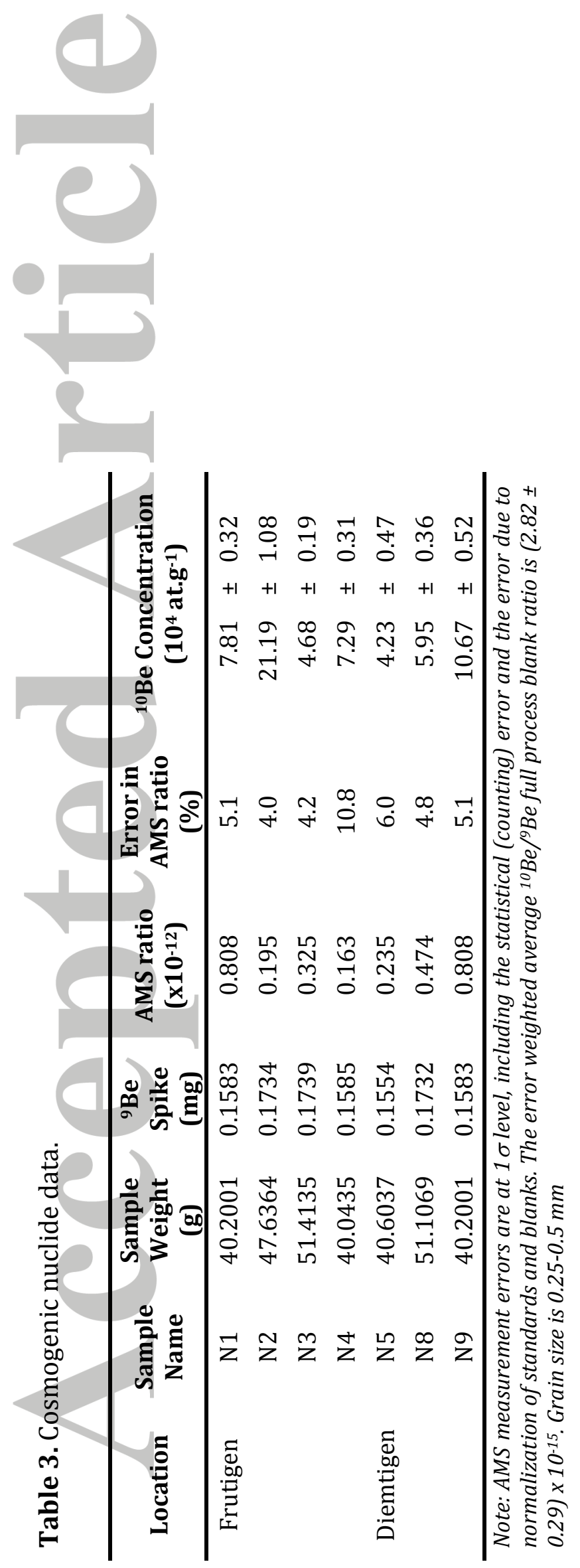

This article is protected by copyright. All rights reserved. 


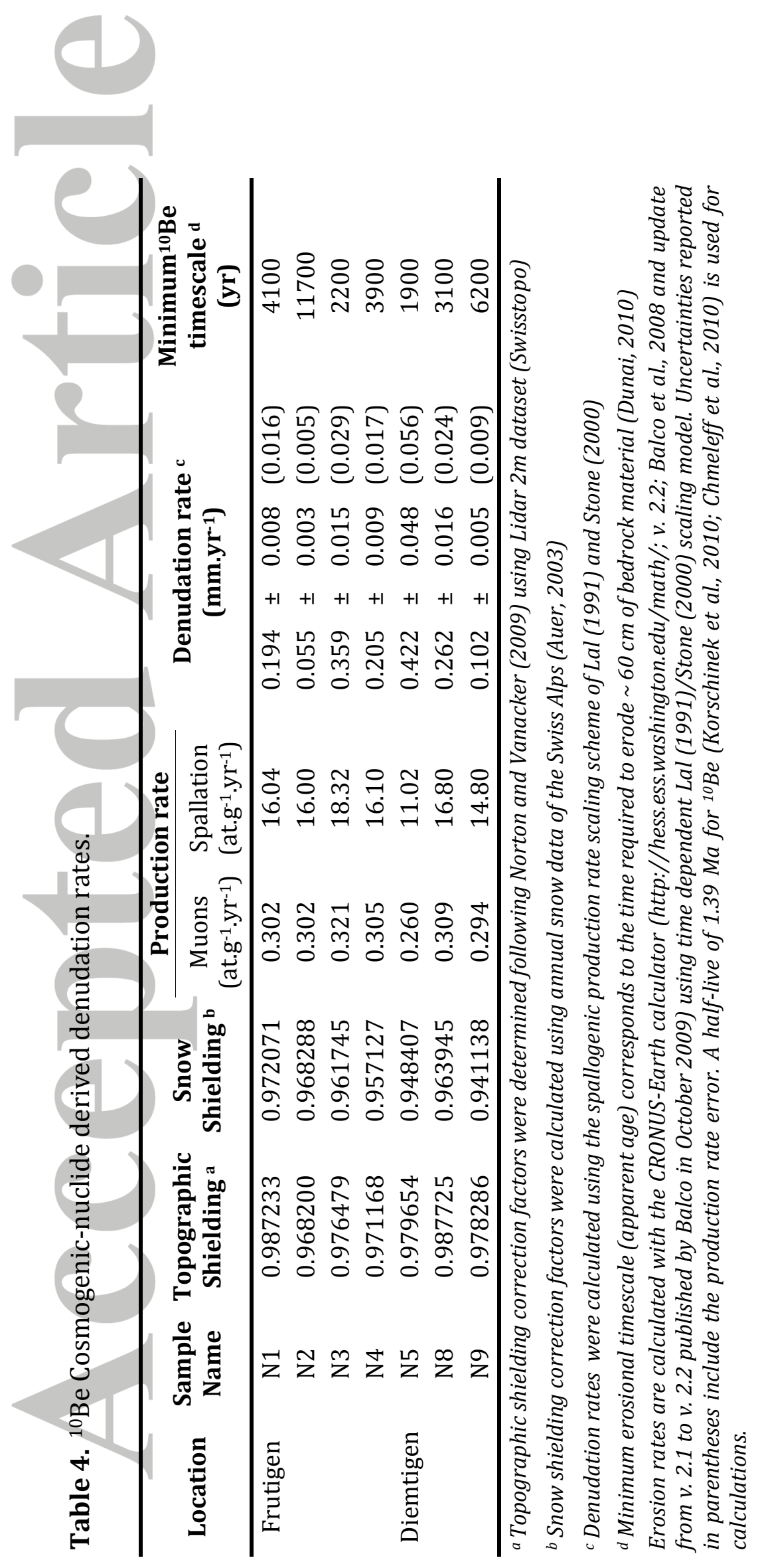

This article is protected by copyright. All rights reserved. 